\title{
Dust aerosol radiative effects during summer 2012 simulated with a coupled regional aerosol-atmosphere-ocean model over the Mediterranean
}

\author{
P. Nabat ${ }^{1}$, S. Somot ${ }^{1}$, M. Mallet ${ }^{2}$, M. Michou ${ }^{1}$, F. Sevault ${ }^{1}$, F. Driouech ${ }^{3}$, D. Meloni ${ }^{4}$, A. di Sarra ${ }^{4}$, C. Di Biagio ${ }^{5}$, \\ P. Formenti ${ }^{5}$, M. Sicard ${ }^{6}$, J.-F. Léon ${ }^{2}$, and M.-N. Bouin ${ }^{7}$ \\ ${ }^{1}$ Météo-France, CNRM-GAME, Centre national de recherches météorologiques, UMR3589, Toulouse, France \\ ${ }^{2}$ Laboratoire d'Aérologie, Toulouse, France \\ ${ }^{3}$ Direction de la Météorologie Nationale, Casablanca, Morocco \\ ${ }^{4}$ Laboratory for Earth Observations and Analyses, ENEA, Rome, Italy \\ ${ }^{5}$ Laboratoire interuniversitaire des systèmes atmosphériques (LISA), UMR7583 - CNRS, Créteil, France \\ ${ }^{6}$ Universitat Politechnica de Catalunya, Barcelona, Spain \\ ${ }^{7}$ Météo-France, CMM, Centre de Météorologie Marine, Brest, France \\ Correspondence to: P. Nabat (pierre.nabat@meteo.fr)
}

Received: 1 July 2014 - Published in Atmos. Chem. Phys. Discuss.: 6 October 2014

Revised: 19 February 2015 - Accepted: 2 March 2015 - Published: 24 March 2015

\begin{abstract}
The present study investigates the radiative effects of dust aerosols in the Mediterranean region during summer 2012 using a coupled regional aerosol-atmosphere-ocean model (CNRM-RCSM5). A prognostic aerosol scheme, including desert dust, sea salt, organic, black-carbon and sulphate particles, has been integrated to CNRM-RCSM5 in addition to the atmosphere, land surface and ocean components. An evaluation of this aerosol scheme of CNRM-RCSM5, and especially of the dust aerosols, has been performed against in situ and satellite measurements, showing its ability to reproduce the spatial and temporal variability of aerosol optical depth (AOD) over the Mediterranean region in summer 2012. The dust vertical and size distributions have also been evaluated against observations from the TRAQA/ChArMEx campaign. Three simulations have been carried out for summer 2012 with CNRM-RCSM5, including the full prognostic aerosol scheme, only monthly-averaged AOD means from the aerosol scheme or no aerosols at all, in order to focus on the radiative effects of dust particles and the role of the prognostic scheme. Surface short-wave aerosol radiative forcing variability is found to be more than twice as high over regions affected by dust aerosols, when using a prognostic aerosol scheme instead of monthly AOD means. In this case downward surface solar radiation is also found to be better reproduced according to a comparison with several stations across
\end{abstract}

the Mediterranean. A composite study over 14 stations across the Mediterranean, designed to identify days with high dust AOD, also reveals the improvement of the representation of surface temperature brought by the use of the prognostic aerosol scheme. Indeed the surface receives less radiation during dusty days, but only the simulation using the prognostic aerosol scheme is found to reproduce the observed intensity of the dimming and warming on dusty days. Moreover, the radiation and temperature averages over summer 2012 are also modified by the use of prognostic aerosols, mainly because of the differences brought in short-wave aerosol radiative forcing variability. Therefore this first comparison over summer 2012 highlights the importance of the choice of the representation of aerosols in climate models.

\section{Introduction}

Numerous and various aerosols affect the Mediterranean basin (Lelieveld et al., 2002), located at the crossroads of air masses carrying both natural (desertic particles, sea salt, volcanic ashes, etc.) and anthropogenic (black carbon, sulphate, etc.) particles. Because of their microphysical and optical properties, these aerosols can have strong effects on the 
regional radiative budget (e.g. Bergamo et al., 2008), with ensuing impact on climate (Zanis et al., 2012; Spyrou et al., 2013; Nabat et al., 2015) and ecosystems of the Mediterranean (Guieu et al., 2010). Among these aerosols, the Saharan desert dust particles represent an important contribution of aerosols for this region (Barnaba and Gobbi, 2004; Nabat et al., 2013). Indeed, dust particles coming from suspension, saltation and creeping processes associated with wind erosion (Knippertz and Todd, 2012) can move from northern Africa to the Mediterranean Sea and Europe (Moulin et al., 1997; Papadimas et al., 2008; Gkikas et al., 2013). These dust outbreaks are mainly driven by the synoptic meteorological conditions (Gkikas et al., 2012): they are more frequent in the eastern basin in winter and spring, in the central basin in spring and in the western basin in summer (Moulin et al., 1998). The ChArMEx initiative (Chemistry-Aerosol Mediterranean Experiment, http://charmex.lsce.ipsl.fr) has been launched for a few years in the framework of the MISTRALS (Mediterranean Integrated STudies at Regional And Local Scales) programme in order to improve our knowledge of aerosols and their impacts on climate in the Mediterranean. Thus, in early summer 2012, the ChArMEx/TRAQA (TRansport and Air QuAlity) campaign focused on the characterization of the polluted air masses over the Mediterranean basin through the study of representative case studies. A particularly intense dust event has been measured at the end of June with different observation means (balloons, aircraft, surface and remote-sensing measurements) and consequently represents a documented case to evaluate the aerosol schemes of regional climate models. Indeed the analysis of study cases is made possible by the use of a reanalysis as lateral boundary forcing which provides the real chronology of these events.

The aim of the present work is consequently to evaluate the direct and semi-direct effects of dust particles during summer 2012 both at the daily time scale and at the summer scale. We consider here a modelling approach with the following requirements. First of all, in order to simulate dust outbreaks, models need prognostic dust schemes (emission, transport, deposition) to uplift dust particles from arid areas and transport them in the atmosphere. Many climate models indeed use only monthly aerosol climatology (e.g. Tanré et al., 1984; Tegen et al., 1997) that cannot correspond to this kind of study. However, disregarding the chemistry-transport models (e.g. CHIMERE, MOCAGE) that do not have aerosolclimate interactions, several aerosol schemes already exist in different climate models (e.g. MACC, ECHAM-HAM, IPSL), evaluated in different intercomparison exercises (e.g. AEROCOM, Schulz et al., 2006, ACCMIP, Lamarque et al., 2013). With regards to dust aerosols, most of the climate models can simulate the main patterns of dust emission and transport (Woodage et al., 2010), but large uncertainties remain in the characterization of dust properties and the resulting impact on climate (Huneeus et al., 2011; Mahowald et al., 2013) notably because of differences in dust emission parameterizations (Todd et al., 2008). Over the Euro-Mediterranean region, several studies have considered the effects of aerosols on climate using simulations with a prognostic scheme, both for anthropogenic aerosols (Zanis, 2009; Vogel et al., 2009; Meier et al., 2012) and dust particles (Santese et al., 2010; Spyrou et al., 2013). Moreover, the role of the Mediterranean Sea is essential in climate feedbacks (Somot et al., 2008; Artale et al., 2010; Herrmann et al., 2011), so that ocean-atmosphere coupled regional models have recently been developed (Krzic et al., 2011; Herrmann et al., 2011; Mariotti and Dell' Aquila, 2012; L'Hévéder et al., 2012; Turuncoglu et al., 2013; Nabat et al., 2015). The importance of this coupling in the aerosolclimate interactions in the Mediterranean has even been recently highlighted (Nabat et al., 2015). However, up to now, aerosol-climate studies with prognostic aerosol schemes have been achieved either with the COSMO (Vogel et al., 2009) or with the RegCM model (Giorgi et al., 2012) and have not included an ocean-atmosphere coupling yet, even if an ocean-atmosphere coupling is currently developed between RegCM and ROMS (Turuncoglu et al., 2013).

In addition, as the Mediterranean is also characterized by local winds, complex coastlines and orography, highresolution modelling is needed to correctly reproduce the atmospheric circulation (Gibelin and Déqué, 2003; Gao et al., 2006; Giorgi and Lionello, 2008).

From our knowledge, none of these regional models can have simultaneous ocean-atmosphere coupling and prognostic aerosol schemes. In the present study, a new version of the coupled regional climate model system (RCSM) of the CNRM, called CNRM-RCSM5, has been developed, including an aerosol prognostic scheme derived from the GEMS/MACC project (Morcrette et al., 2009; Michou et al., 2014) in addition to the atmosphere, ocean and land-surface components. This new model tool thus complies with all the criteria mentioned above and should be able to help us to evaluate the direct and semi-direct effects of dust aerosols at the daily time scale. The data brought by the TRAQA campaign provide the opportunity to a first evaluation of the dust aerosol scheme before assessing the radiative aerosol effects. Additionally, including the other aerosol species allows a comparison of total aerosol optical depth (AOD) with remote-sensing measurements. Thus the present work aims at studying the radiative effects of dust aerosols in the Mediterranean area during summer 2012. The question of the difference between the use of climatological and prognostic aerosols in this model will also be raised, notably to study the consequences of this choice both on the daily and seasonal (for summer) variability of different meteorological parameters (radiation, temperature, cloud cover).

After a description of the aerosol scheme in Sect. 2 and its evaluation in Sect. 3, the radiative effects of aerosols are studied in Sect. 4 before the concluding remarks in Sect. 5 . 


\section{Methodology}

\subsection{The CNRM-RCSM5 model}

Four different components are included in this regional climate model system: the atmosphere with the regional climate model ALADIN-Climate (Déqué and Somot, 2008; Colin et al., 2010), the ocean with the regional model NEMOMED8 (Beuvier et al., 2010), the land-surface with the model ISBA (Noilhan and Mahfouf, 1996) and the aerosols, simulated interactively within ALADIN-Climate (see details in 2.2). ALADIN-Climate is a bi-spectral semiimplicit semi-Lagrangian regional model with a $50 \mathrm{~km}$ horizontal resolution and 31 vertical levels in the present work. The version 5.3 is used here bringing some improvements compared to the previous version 5.2 used in Nabat et al. (2015). As in the version used in Lucas-Picher et al. (2013), the long-wave (LW) radiation scheme is now based on the rapid radiation transfer model (RRTM, Mlawer et al., 1997), while the short-wave (SW) scheme initially developed by Morcrette (1989) has a finer spectral resolution (six bands). We also use here a spectral nudging method described in Radu et al. (2008), which enables us to keep large scales from the boundary forcing and thus impose the true natural climate variability that is essential to represent dust events notably. Here the wind vorticity and divergence, the surface pressure, the temperature and the specific humidity are nudged. The function used imposes a constant rate above $700 \mathrm{hPa}$ and a relaxation zone between 700 and $850 \mathrm{hPa}$, while the levels below $850 \mathrm{hPa}$ are free. The spatial wavelengths are similarly nudged beyond $400 \mathrm{~km}$, with a relaxation zone between 200 and $400 \mathrm{~km}$. Thus this method gives the model enough freedom to generate the aerosols at the surface while keeping the large scale conditions that are essential to simulate the true chronology.

The ocean model NEMOMED8 and the land surface model ISBA are the same models as used in Nabat et al. (2015). The ocean-atmosphere coupling is achieved by the OASIS3 coupler (Valcke, 2013) at a $3 \mathrm{~h}$ frequency, which represents an improvement compared to CNRM-RCSM4 described in Nabat et al. (2015). Note finally that contrary to CNRM-RCSM4, the coupling to the river routine scheme is not included in the present version of CNRM-RCSM5.

\subsection{The aerosol scheme in ALADIN-Climate}

Until the version 5.2 of ALADIN-Climate aerosols were represented in this model through monthly climatologies of aerosol optical depth for five aerosol types (desert dust, sea salt, black carbon, organic matter and sulphate) distributed vertically according to constant profiles. In the version 5.3 used here, a prognostic aerosol scheme has been included, adapted from the GEMS/MACC aerosol scheme (Morcrette et al., 2009; Benedetti et al., 2011; Michou et al., 2014). It includes the same five aerosol species that can be directly emit- ted from the surface for dust and sea-salt particles or from external emission data sets for black carbon, organic matter and sulphate precursors. The spatial domain of our simulations has consequently been extended compared to the previous study of Nabat et al. (2015) in order to include all the sources generating aerosols that can be transported over the Mediterranean basin. As far as dust particles are concerned (Middleton and Goudie, 2001; Israelevich et al., 2012), the following sources are notably included in the domain: North African sources (Morocco, Algeria, Tunisia), the Hoggar mountains, the Tibesti Mountains, the Bodélé depression, Libya, Egypt and sources near the Red Sea (northeast Sudan, Djibouti). No aerosol is included in the lateral boundary forcing.

Sea-salt aerosols are generated by wind stress on ocean surface either because of air bubbles bursting at the sea surface or from spume droplets directly torn off the wave crests by the wind. Guelle et al. (2001) have reviewed different approaches to model these processes. The current formulation used in ALADIN-Climate is based on the studies of Guelle et al. (2001) and Schulz et al. (2004) that provide surface mass fluxes at $80 \%$ relative humidity depending on $10 \mathrm{~m}$ wind, integrated for the three size bins defined in the scheme: 0.03 to $0.5,0.5$ to 5 and 5 to $20 \mu \mathrm{m}$. Note that the size distribution of emitted sea salt also depends on other factors, such as the sea surface temperature (Jaeglé et al., 2011), which are not taken into account in this current version. Dust emission processes depend on several factors such as soil characteristics (chemical composition, humidity, roughness) and surface wind speed. In the GEMS/MACC scheme, the dust parameterization follows Ginoux et al. (2001), who propose a simplified formulation of dust emission based on the wind speed and thresholds according to the fraction of bare soil and soil moisture. In ALADIN-Climate, this function has been replaced by the Marticorena and Bergametti (1995) parameterization that takes into account more soil characteristics coming from the ECOCLIMAP database (Masson et al., 2003), which provides information on the erodible fraction and the sand and clay fractions, allowing a classification of the soil textures. After the determination of an erosion threshold based on the soil distribution, the soil moisture and the roughness caused by nonerodible elements, the horizontal saltation flux is calculated proportionally to the third power of the wind friction velocity. The vertical flux is then inferred from this saltation flux, according to an empirical relationship given by Marticorena and Bergametti (1995), which notably depends on the soil clay content. The emitted dust size distribution is based on the work of Kok (2011). More details about this dust emission parameterization can be found in Nabat et al. (2012), who have used the same dust emission scheme in RegCM4. Once emitted dust particles are integrated in the three dust size bins of the scheme: 0.01 to $1.0,1.0$ to 2.5 and 2.5 to $20 \mu \mathrm{m}$.

The external emission data sets for the three other aerosol types come from Lamarque et al. (2010), who have provided inventories at $0.5^{\circ}$ resolution of different species for climate 


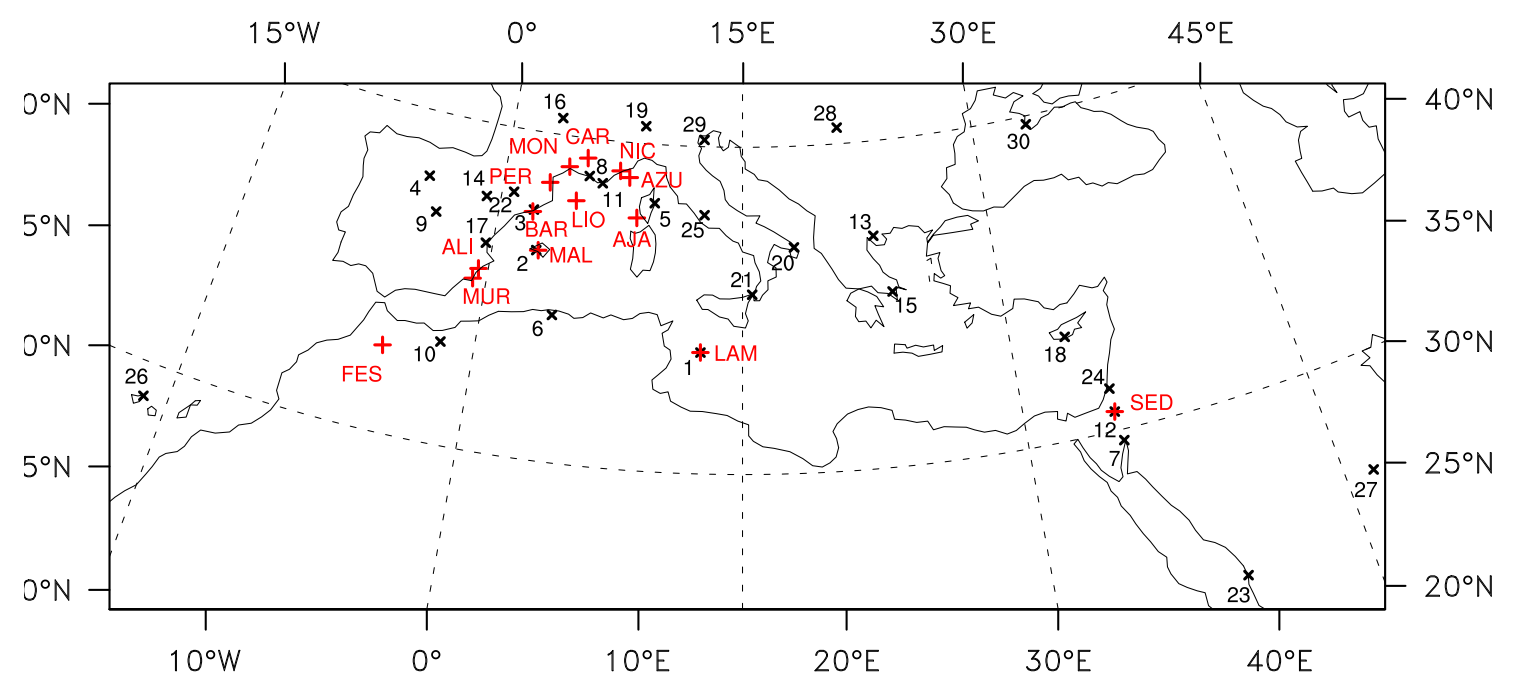

Figure 1. Stations of the AERONET network (black crosses, see the list of the corresponding numbers in Fig. 4). Red crosses indicate the stations providing measurements of surface radiation and temperature (see the list in Table 1).

models. These inventories include numerous sectors such as energy production, industries, domestic activities, agriculture, transport and fires. Organic and black carbon particles are separated between hydrophile and hydrophobic particles. $\mathrm{SO}_{2}$ emitted particles can be transformed in $\mathrm{SO}_{4}$, but $5 \%$ of them are directly emitted as $\mathrm{SO}_{4}$ aerosols (Benkovitz et al., 1996). Volcanic sulfur emissions are also included, as well as dimethylsulfide particles from oceans (see Michou et al., 2014).

All these aerosols gathered in 12 bins are then transported in the atmosphere before possible dry or wet deposition. More details about transport and deposition can be found in Morcrette et al. (2009). Optical properties (single scattering albedo and asymmetry factor) are fixed for each aerosol type, as defined in Nabat et al. (2013). The complexity of this aerosol scheme is similar to the one used in RegCM, but it does not include detailed chemical processes that can be found in COSMO-ART (Vogel et al., 2009). However, it enables our model to keep a low cost of calculations so that multi-annual simulations could be carried out for aerosolclimate studies. Note also that nitrate aerosols are not considered in this model.

\subsection{Simulations}

Three simulations have been carried out with CNRMRCSM5, driven by the ERA-Interim reanalysis (Dee et al., 2011) as initial and lateral boundary forcing. First of all, the PROG simulation includes the whole aerosol prognostic scheme described previously. Secondly, in order to estimate the effect of aerosols on meteorological variables such as temperature and radiation, a simulation without aerosols is needed: the NO simulation does not include any aerosols. Thirdly, as the objective of this study is also to discuss the choice of using climatological or prognostic aerosols, another simulation, called PROG-M, uses monthly AOD provided by PROG so that PROG and PROG-M share the same average aerosol content at the monthly scale. Comparisons between these simulations will enable us to estimate the aerosol effects on the radiative budget and regional climate and the implications of using a prognostic aerosol scheme instead of monthly climatologies. While an improvement on daily SW radiation variability is expected with the use of prognostic aerosols, it is more difficult to answer a priori for other daily parameters, $2 \mathrm{~m}$ temperature (T2m) and sea surface temperature (SST), and more generally for consequences on the summer average. The three simulations cover the summer 2012 period from 1 June to 31 August. A 1month spin-up period has been performed for each simulation in order to have realist aerosol concentrations on 1 June.

\subsection{Observation data}

For the evaluation of the aerosols and their direct radiative effects, different observed data sets are used in the present work.

Simulated AOD is compared to satellite data from the MODerate resolution Imaging Spectroradiometer (MODIS, collection 5.1, standard and Deep Blue algorithms, $1^{\circ}$ resolution; Tanré et al., 1997; Levy et al., 2007), the Multiangle Imaging SpectroRadiometer (MISR, Level3; Kahn et al., 2005, 2010) and the SEVIRI radiometer onboard the geostationary satellite Meteosat Second Generation. For the latter instrument, we use the algorithm of Carrer et al. (2010), which provides high-resolution AOD over both ocean and land surfaces. Nowadays, this algorithm is being implemented on the production chain of the ICARE thematic centre (http://www.icare.univ-lille1.fr) under the name of 
Table 1. Stations used for the composite study. The total number of days when observations are available and among them the number of dusty days have been indicated.

\begin{tabular}{llrrrr}
\hline Short name & Station & Lat & Long & Available days & Dusty days \\
\hline MUR & Murcia & 37.8 & -0.8 & 83 & 23 \\
BAR & Barcelona & 41.3 & 2.1 & 85 & 10 \\
MAL & Palma de Mallorca & 39.6 & 2.6 & 74 & 13 \\
ALI & Alicante & 38.3 & -0.6 & 90 & 15 \\
AJA & Ajaccio & 41.6 & 8.5 & 88 & 7 \\
CAR & Carpentras & 44.1 & 5.1 & 84 & 4 \\
MON & Montpellier & 43.6 & 4.0 & 75 & 7 \\
NIC & Nice & 43.7 & 7.2 & 88 & 4 \\
PER & Perpignan & 42.7 & 2.9 & 80 & 6 \\
FES & Fès & 33.9 & -5.0 & 61 & 36 \\
LIO & Gulf of Lions (buoy) & 42.1 & 4.6 & 83 & 9 \\
AZU & Azur (buoy) & 43.4 & 7.8 & 78 & 5 \\
LAM & Lampedusa & 35.5 & 12.6 & 89 & 24 \\
SED & Sde Boker & 30.9 & 34.8 & 92 & 5 \\
\hline
\end{tabular}

AERUS-GEO (Aerosol and surface albEdo Retrieval Using a directional Splitting method; application to GEO data by Carrer et al., 2014), a daytime averaged product.

Ground-based observations from 30 stations of the AErosol RObotic NETwork (AERONET, Holben et al., 1998, 2001) will also be considered (Fig. 1). These sunphotometer observations provide high-quality data (Level 2.0), which have been downloaded from the AERONET website (http://aeronet.gsfc.nasa.gov). All AOD data have been calculated at $550 \mathrm{~nm}$ using the Ångstrom coefficient when necessary to make comparisons and evaluation easier.

The TRAQA campaign has also provided interesting observations for dust aerosols, namely vertical profiles from lidar instruments in Barcelona and San Giuliano (Corsica). The Barcelona lidar system is part of the ACTRIS/EARLINET network (Aerosols, Clouds, and Trace gases Research InfraStructure Network/European Aerosol Research Lidar Network, Pappalardo et al., 2014). The extinction coefficient profiles were retrieved by means of the two-component elastic lidar inversion algorithm constrained with the AERONET sun-photometer-derived AOD (Reba et al., 2010). In San Giuliano $\left(42.28^{\circ} \mathrm{N}, 9.51^{\circ} \mathrm{E}\right)$, aerosol vertical profiles were acquired with a $355 \mathrm{~nm}$ backscattering lidar. The aerosol extinction coefficient profiles are estimated using the Klett's method and a fixed lidar ratio (Léon et al., 2015) from hourly averaged attenuated range-corrected lidar signals. Additionally, an ATR-42 research flight operated by SAFIRE (Service des avions français instrumentés pour la recherche en environnement) has also been realized during the TRAQA campaign. This study uses the airborne data from the Passive Cavity Aerosol Spectrometer Probe (PCASP), which measures particles between 0.1 and $3.2 \mu \mathrm{m}$.

In addition, the Météo-France and AEMET networks have provided daily radiation and $2 \mathrm{~m}$ temperature measurements (see Fig. 1 and Table 1). Radiation measurements have been completed by the stations of Sde Boker (SED, SolRadNet network, AERONET website), Lampedusa (LAM, coll. ENEA) and two Météo-France buoys located in the Gulf of Lions (LIO) and near the French Riviera (AZU). Lampedusa and the two buoys also provide SST measurements. All 14 stations providing surface radiation and temperature have been added in Fig. 1 (red crosses). It is worth mentioning that available data are provided by stations that are located for most of them in the western Mediterranean. However, in summer most of the dust outbreaks occur in this region because of frequent low-pressure systems over Morocco that favour the dust export over the western Mediterranean (Moulin et al., 1998; Gkikas et al., 2012).

Additionally, the MACC reanalysis (Morcrette et al., 2009) is also used in the present work as a means of evaluating the CNRM-RCSM5 simulations. This reanalysis includes data assimilation of AOD from the MODIS instrument.

\section{Evaluation of the simulated aerosols}

In this section, an evaluation of the simulated aerosols during summer 2012 is carried out against different available observations and climatologies. Depending on the parameter, several types of data sets are indeed required.

\subsection{Total AOD: spatial evaluation}

The AOD spatial distribution is firstly evaluated against different satellite products (MODIS, MISR and AERUS-GEO). The average total AOD in summer 2012 for each data set is shown in Fig. 2. The general spatial pattern shows a good agreement between satellites and CNRM-RCSM5. The highest values (up to 1.5) are indeed found over northern Africa and Arabian peninsula while the Mediterranean Sea is af- 


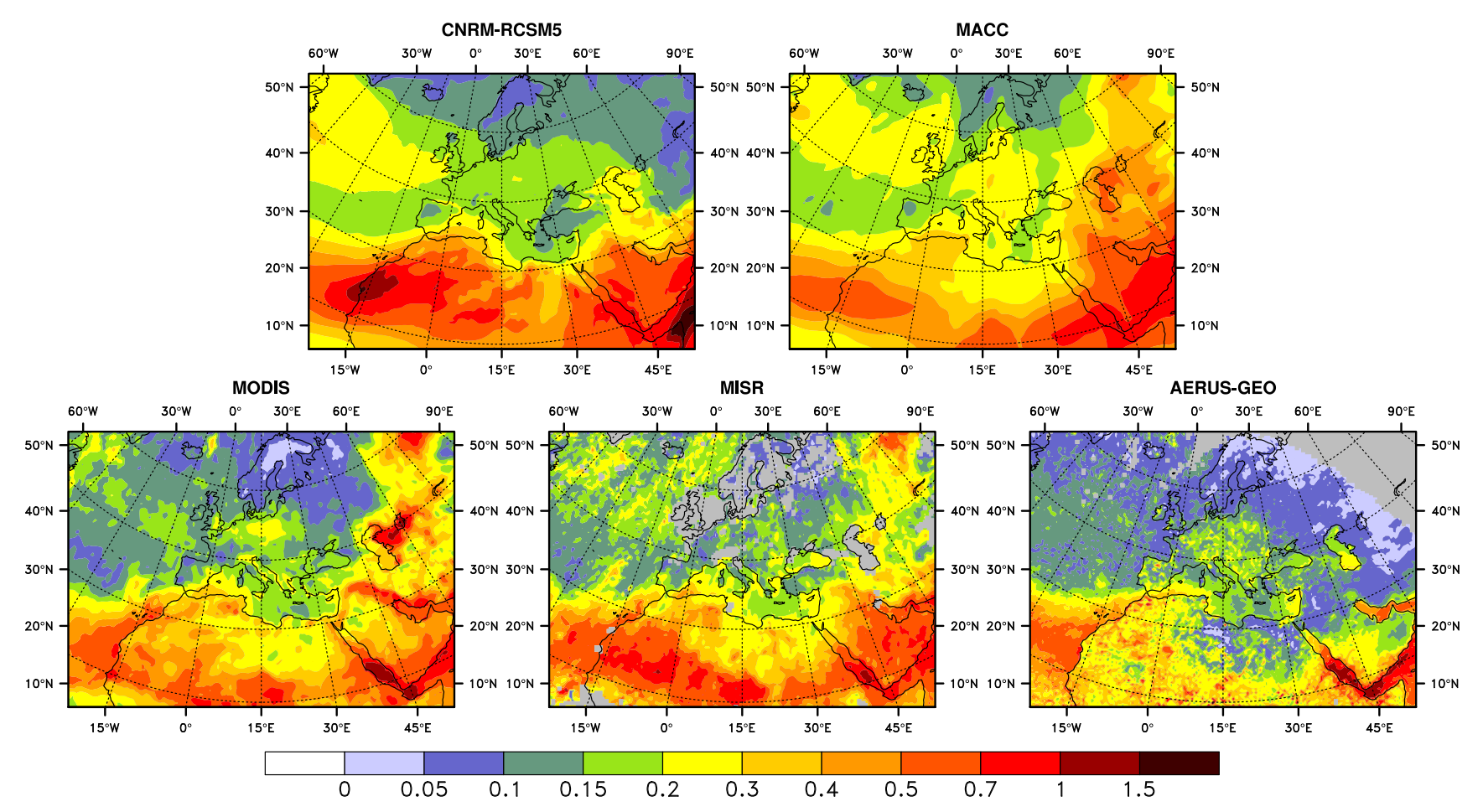

Figure 2. Mean aerosol optical depth at $550 \mathrm{~nm}$ in summer 2012 (JJA) simulated by CNRM-RCSM5 and MACC (top) and measured by three satellite instruments (MODIS, MISR and AERUS-GEO, bottom).

Table 2. Spatial correlation coefficients between AOD of the different data sets presented in Fig. 2.

\begin{tabular}{lrrrr}
\hline Data sets & MODIS & MISR & AERUS-GEO & MACC \\
\hline CNRM-RCSM5 & 0.64 & 0.77 & 0.65 & 0.74 \\
MODIS & & 0.81 & 0.69 & 0.84 \\
MISR & & & 0.68 & 0.84 \\
AERUS-GEO & & & & 0.61 \\
\hline
\end{tabular}

fected by moderate AOD, ranging from 0.15 to 0.3 , from the north-east to the south-west.

In greater detail, some differences can be noted between the model and satellite data. CNRM-RCSM5 AOD is closer to MISR over northern Africa, where a large zone of AOD higher than 0.5 can be identified in both data sets, while MODIS and especially AERUS-GEO show lower AOD. Similar conclusions can be drawn for the Arabian peninsula. Dust export over the Atlantic Ocean is, on the contrary, in very good agreement between the five products (AOD between 0.5 and 0.7). Over western and central Europe, MISR AOD is lower than MODIS, AERUS-GEO and CNRMRCSM5. Large differences in AOD are also present in Eastern Europe and Russia, where MODIS shows higher AOD than the other data sets. However, this region is in the limit of the domain seen by SEVIRI (lower values in AERUS-GEO) and is also close to the border of the domain used in CNRM-
RCSM5, so that aerosols over this region may come from outside the domain. Finally, AOD over the northern Atlantic Ocean is higher in CNRM-RCSM5 than in satellite products, but the presence of numerous clouds in this area limits the quality of the satellite data there.

In summary, Table 2 presents the spatial correlations between these four products. All the correlations are higher than 0.6 , confirming the general agreement and the ability of CNRM-RCSM5 to reproduce the main spatial patterns of AOD.

\subsection{Total AOD: temporal evaluation}

As far as the temporal dimension is concerned, an evaluation has been realized against ground-based measurements from the AERONET network in the Mediterranean area in terms of daily means. Indeed, AERONET measurements benefit from a higher temporal resolution than data from moving satellites and their accuracy is generally higher, about \pm 0.01 (Holben et al., 1998) compared to \pm 0.05 for satellites (Kahn et al., 2010; Levy et al., 2010). Figure 3 shows four temporal series across the Mediterranean basin at Oujda (a, Morocco, number 10 in Fig. 1), Mallorca (b, Spain, 2), Frioul (c, France, 8) and Lampedusa (d, Italy, 1). All these series show high daily variability because of frequent dust outbreaks in this season. The spectral nudging technique used in CNRM-RCSM5 enables the model to reproduce the true chronology of the synoptic meteorological conditions as shown in Herrmann 
a) Oujda

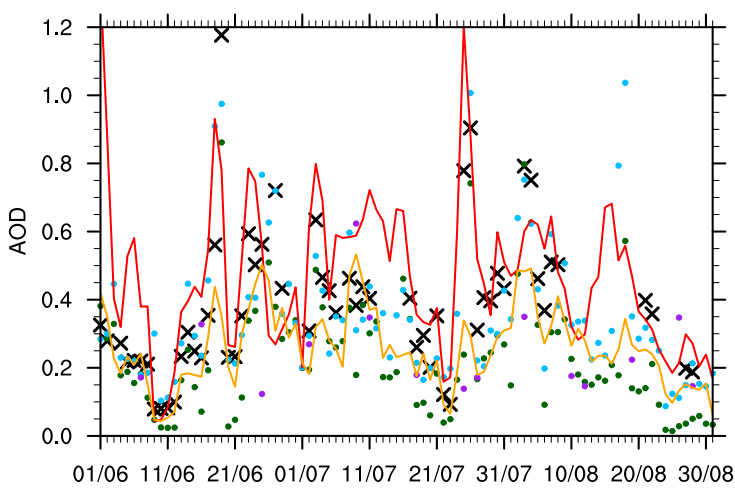

c) Frioul

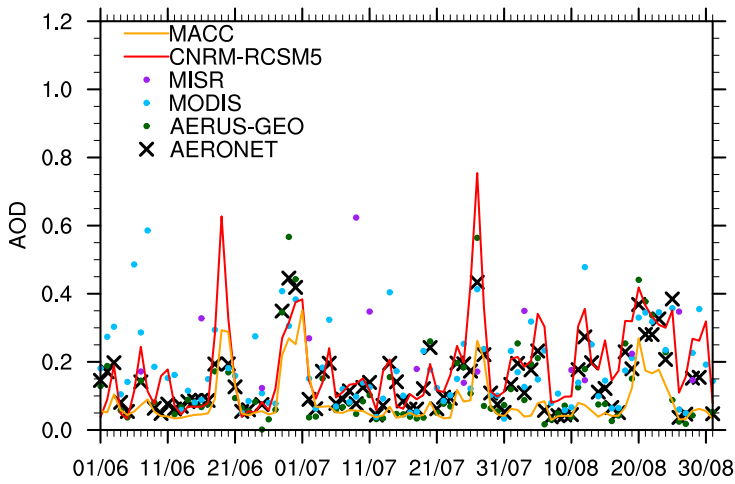

b) Mallorca

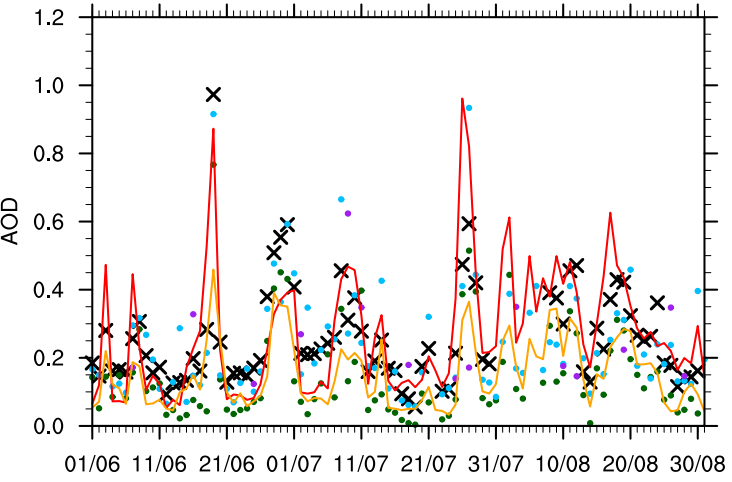

d) Lampedusa

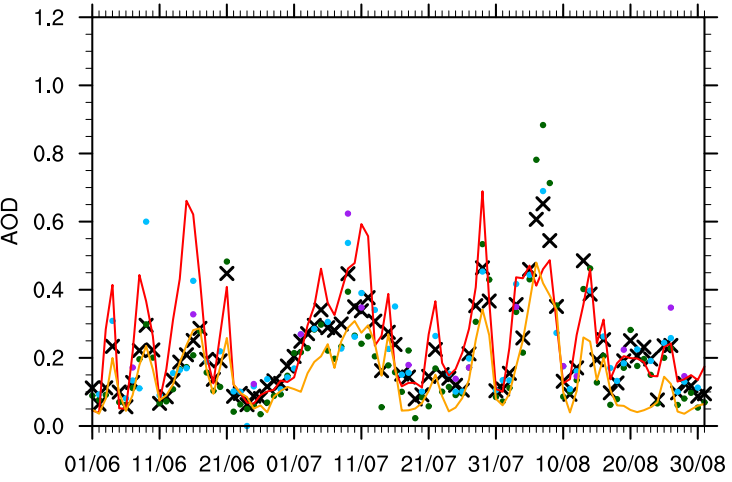

Figure 3. AOD (at $550 \mathrm{~nm}$ ) temporal series between 1 June and 31 August 2012 simulated by CNRM-RCSM5 (red lines) and MACC (orange lines) and observed by AERONET sun photometers (black crosses), MODIS (blue points), MISR (purple points) and AERUS-GEO (green points) at four stations of the AERONET network: Oujda (a, number 10 in Fig. 1), Mallorca (b, 2), Frioul (c, 8) and Lampedusa (d, 1).

et al. (2011), which is useful for driving dust emission in the present work. As a result, the model is able to reproduce the intensity and the chronology of most AOD peaks, such as those observed in Oujda (18 June, 25 July) in Mallorca (19 June, 9 July, 10 August), Frioul (28 June, 19 August) and Lampedusa (21 June, 13 August). However, CNRM-RCSM5 overestimate a few dust events (e.g. 19 June in Frioul, 15 June in Lampedusa), but these differences remain in the minority.

Similar comparisons have been realized for 30 AERONET stations (see their locations in Fig. 1), the results are presented in a Taylor diagram (Fig. 4, adapted to daily time series from Taylor, 2001). This diagram represents three statistics: the correlation coefficient is the azimuth angle, the radial distance from the origin is the standard deviation normalized by observations, and the distance to the "REF" point on the $x$ axis is the root-mean-square error (RMSE). The average temporal correlation coefficient for CNRM-RCSM5 is 0.70, while the ratio between simulated and observed standard deviations is 1.01 , revealing the ability of the aerosol scheme to reproduce AOD daily variability. In addition, CNRMRCSM5 has no station with very low scores and has a low mean bias both when considering all 30 stations (0.02) and only the stations to the south of $33^{\circ} \mathrm{N}(0.03)$.

Additionally, the daily values for the satellite products have been added in Figs. 3 and 4 as information for data users. It is indeed important to note that in terms of daily variability, (1) MODIS and AERUS-GEO have a higher temporal correlation with AERONET (0.73 and 0.76 respectively) than MISR (0.15), probably because of a reduced number of available retrievals with this instrument; (2) AERUS-GEO has the best scores among the satellite products; (3) MODIS and AERUS-GEO have, however, respectively 5 and 3 stations with RMSE higher than 1.25; and (4) all these products have a higher mean bias than CNRM-RCSM5.

\subsection{Contribution of aerosol species to AOD}

Satellites and ground-based measurements do not provide the contribution of the different aerosol types to AOD (the distinction between coarse and fine modes is not sufficient), which is the reason why a comparison to the MACC reanalysis (Morcrette et al., 2009; Benedetti et al., 2011) and the AOD climatology from Nabat et al. (2013), named NAB13 thereafter, is presented in this section. Note that total AOD 
Table 3. Total AOD and components for the five aerosol types simulated by CNRM-RCSM5 and the MACC reanalysis in summer 2012 over Europe (continental area up to $30^{\circ} \mathrm{E}$ ), the Mediterranean Sea and northern Africa (continental area up to $25^{\circ} \mathrm{N}$ ). Averages in summer from NAB13, the climatology of Nabat et al. (2013), have also been indicated with the minimum and maximum summer values (period 2003-2009). Total AOD from satellite data (MODIS, MISR, AERUS-GEO) is also given.

\begin{tabular}{lrrrrrr}
\hline Europe & CNRM-RCSM5 & MACC & NAB13 & MODIS & MISR & AERUS-GEO \\
\hline Sea salt & 0.01 & 0.02 & $0.00[0.00-0.00]$ & - & - & - \\
Desert dust & 0.04 & 0.06 & $0.05[0.04-0.05]$ & - & - & - \\
Organic matter & 0.04 & 0.02 & $0.02[0.02-0.03]$ & - & - & - \\
Black carbon & 0.01 & 0.01 & $0.01[0.01-0.01]$ & - & - & - \\
Sulphate & 0.08 & 0.10 & $0.10[0.08-0.12]$ & - & - & - \\
Total & 0.18 & 0.21 & $0.18[0.16-0.20]$ & 0.16 & 0.15 & 0.15 \\
\hline Mediterranean & & & & & & - \\
\hline Sea salt & 0.01 & 0.02 & $0.01[0.00-0.01]$ & - & - & - \\
Desert dust & 0.11 & 0.10 & $0.12[0.10-0.13]$ & - & - & - \\
Organic matter & 0.03 & 0.02 & $0.01[0.01-0.02]$ & - & - & - \\
Black carbon & 0.01 & 0.01 & $0.01[0.00-0.01]$ & - & - & - \\
Sulphate & 0.07 & 0.09 & $0.08[0.07-0.10]$ & - & - & 0.18 \\
Total & 0.23 & 0.24 & $0.23[0.19-0.25]$ & 0.20 & 0.22 & - \\
\hline Africa & & & & & & - \\
\hline Sea salt & & & & & - \\
Desert dust & 0.00 & 0.01 & $0.00[0.00-0.00]$ & - & - & - \\
Organic matter & 0.37 & 0.18 & $0.31[0.25-0.33]$ & - & - & - \\
Black carbon & 0.02 & 0.02 & $0.01[0.01-0.02]$ & - & - & - \\
Sulphate & 0.01 & 0.01 & $0.01[0.01-0.01]$ & - & - & - \\
Total & 0.05 & 0.07 & $0.08[0.06-0.09]$ & - & - & - \\
\hline & 0.45 & 0.29 & $0.41[0.33-0.44]$ & 0.33 & 0.32 & - \\
\hline
\end{tabular}

of NAB13 corresponds to MODIS AOD by definition of this product and that the total AOD of MACC has been added in Figs. 2, 3, 4 and Table 2 as information for data users.

Figure 5 presents the mean AOD for summer 2012 for the five simulated aerosol types. Dust aerosols prevail in the southern part of the domain because of sources in Sahara and in the Arabian peninsula, while anthropogenic particles, especially sulphate and organic matter, are responsible for local maxima in AOD in Europe. Sea-salt particles are essentially simulated over the Atlantic Ocean, as well as the western Mediterranean Sea in lower quantities.

The different contributions to AOD for each aerosol type are given in Table 3 for CNRM-RCSM5, MACC and NAB13. NAB13 is based on both model and satellite data, and MACC is based on model and data assimilation. NAB13, which gives reliable estimations of the different AOD components, is only available on the 2003-2009 period, so that the average over this period with the minimum and maximum values have been indicated. Averages have been calculated on the three domains defined in Nabat et al. (2013): Europe, the Mediterranean Sea and northern Africa.

Over Europe, CNRM-RCSM5 is very close to NAB13 for total AOD ( 0.18 on average) and the five aerosol types, even if the sharing between organic matter and sulphate aerosols is slightly different. MACC simulate more dust and sulphate particles, but the three satellites' data have lower AOD (be- tween 0.15 and 0.16) so that CNRM-RCSM5 AOD is median. Over the Mediterranean Sea a good agreement is shown among CNRM-RCSM5 (0.23 for total AOD), MACC (0.24) and NAB13 (0.23). In addition, the proportion among the different aerosol types is similar in the three data sets. However, as in Europe, satellite data have lower AOD (between 0.18 and 0.22).

More variability is noted with regards to AOD over northern Africa, notably because of the dust component. CNRMRCSM5 shows higher AOD (0.45) than NAB13 (0.41), MACC (0.32) and the satellite data (between 0.21 and 0.33 ). However, interannual variability is stronger in this region as shown by the larger amplitude in NAB13 (0.33-0.44). Moreover, MACC does not assimilate AOD over the Sahara because the standard algorithm of MODIS cannot retrieve AOD on bright surface, so that an underestimation of dust aerosols in MACC had been identified (Nabat et al., 2013).

In summary, the evaluation of AOD for each aerosol type is complicated because of the heterogeneity among the different data sets, but the contribution of aerosol types to AOD in CNRM-RCSM5 is close to that in MACC and NAB13. It is worth mentioning that CNRM-RCSM5 does not include the nitrate component. However, dust aerosols constitute the main focus of the following paragraphs. 

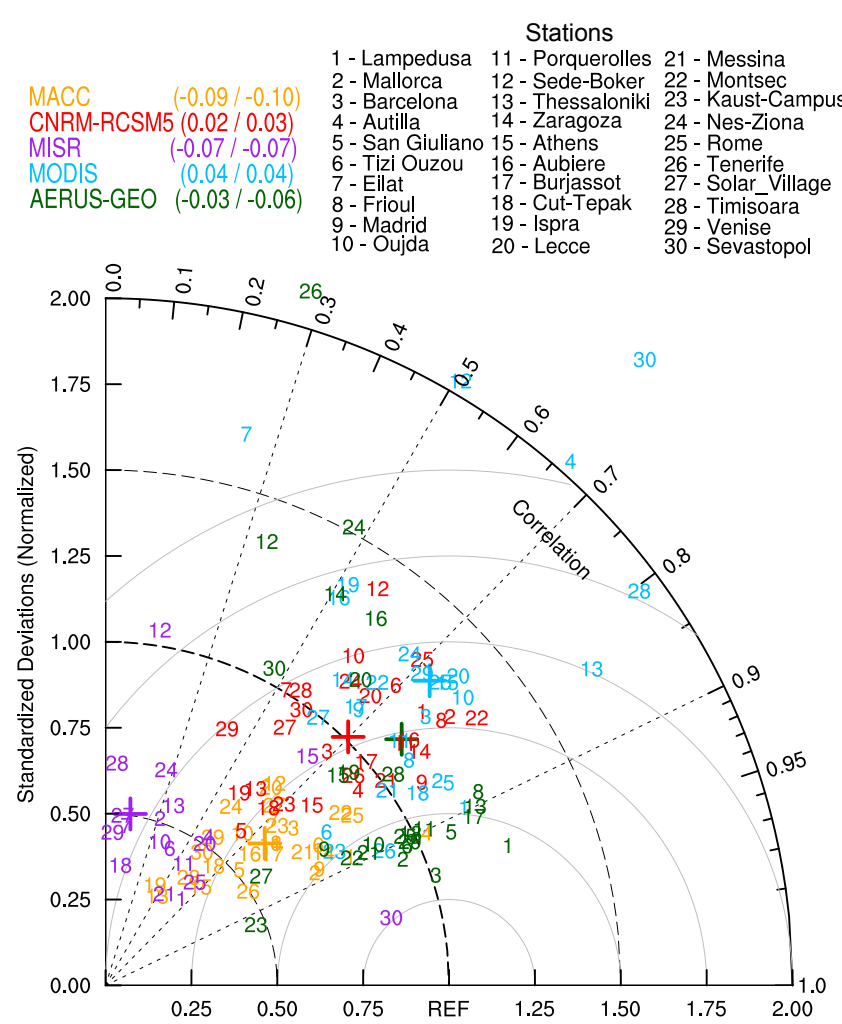

Figure 4. Taylor diagram evaluating CNRM-RCSM5 (red), MACC (orange) and satellite (MODIS in blue, MISR in purple and AERUS-GEO in green) data against 30 AERONET ground-based observations in terms of daily AOD in summer 2012. Averages over the 30 stations for each data set are indicated with crosses. The mean bias against AERONET is indicated in the caption between brackets (all 30 stations $/ 9$ stations located to the north of $33^{\circ} \mathrm{N}$ ).

\subsection{Dust extinction vertical profile}

CNRM-RCSM5 has shown its ability to reproduce AOD daily evolution correctly, which is a parameter often evaluated in climate models. However, aerosol direct and semidirect forcing also depend on the profile and size distribution of particles, rarely evaluated given the scarcity of observations and affected by large uncertainties (Textor et al., 2006). Even if total AOD is necessary to evaluate AOD against in situ or satellite measurements that cannot separate the different aerosol types, more attention is now given to the dust component which is the focus of this study. The TRAQA campaign has well documented a dust outbreak over the Mediterranean Sea, which is useful for this evaluation. However, a deeper evaluation of the other aerosol components is outside of the scope of this paper.

The dust plume observed in the TRAQA campaign comes from the uplift of dust particles in western Africa between 21 and 23 June. These particles have been transported along the African coast up to southern Spain, driven by the presence of a low pressure system over Morocco and a high pres- sure area over the Azores. From 26 June, a low formed in the bay of Biscay generated a south-westerly flow, bringing the dust plume over northern Spain. Successively moving to the southeast, dust particles have also been transported over the Mediterranean Sea. Figure 6 presents the vertical distribution of aerosols during the dust outbreak observed by lidars in the TRAQA campaign in terms of extinction coefficient in Barcelona at $532 \mathrm{~nm}$ and in San Giuliano at $355 \mathrm{~nm}$. Dust aerosols first reach Spain on 27 June, transported in the midtroposphere, as noted in the profile between 2000 and $5000 \mathrm{~m}$ with a maximum extinction $\left(0.18 \mathrm{~km}^{-1}\right)$ at $3500 \mathrm{~m}$. The twocomponent elastic lidar inversion algorithm constrained with an AERONET AOD of 0.32 gave a column-equivalent lidar ratio of $54 \mathrm{sr}$. This value is in the range of 50-70 sr established by Tesche et al. (2009) of desert dust lidar ratio observations by Raman lidar, which makes us confident of the result of the lidar inversion. The altitude of these dust particles is quite similar in CNRM-RCSM5 despite an underestimation of the intensity of the dust outbreak and a slight overestimation in the higher layers. Under this dust layer, the presence of sulphate aerosols is noted in the model, with an extinction coefficient close to observations $\left(0.03 \mathrm{~km}^{-1}\right)$. In San Giuliano, where the dust plume has arrived 3 days later, its altitude is also similar in CNRM-RCSM5 and observations: between 2000 and $5000 \mathrm{~m}$. As in Barcelona, extinction is slightly overestimated in the high troposphere (above $6500 \mathrm{~m}$ ).

In summary, the dust extinction simulated profiles have been evaluated against these lidar profiles, showing the variability in the altitudes of dust aerosols. It should also be mentioned that two profiles are not sufficient to conclude on the ability of the model to estimate the dust vertical distribution. This kind of comparison would need to be done for other places and situations; however, it is a difficult exercise because evaluating only the aerosol vertical distribution requires finding cases where adequate observations are available and where the model correctly simulates the transport of dust aerosols.

\subsection{Dust vertical size distribution}

Size distribution is also an essential physical parameter for aerosol-climate studies, as optical properties depend on the particle size. Figure 7 presents the size distribution observed during a sounding realized by the ATR42 during the TRAQA campaign as well as the simulated distribution. Note that the bin scheme used in CNRM-RCSM5 does not enable the model to reproduce exactly the observed distribution, but the division in three bins for dust particles notably can still be evaluated. This sounding took place in the Mediterranean Sea $\left(43.05^{\circ} \mathrm{N}, 9.55^{\circ} \mathrm{E}\right)$ on $29 \mathrm{June}$, when the dust plume has been transported over this area. In the lower layers, a first maximum is observed in the smallest particles (around $0.1 \mu \mathrm{m}$ ), probably due to sulphate aerosols, as represented by CNRM-RCSM5. The observed distribution shows that 


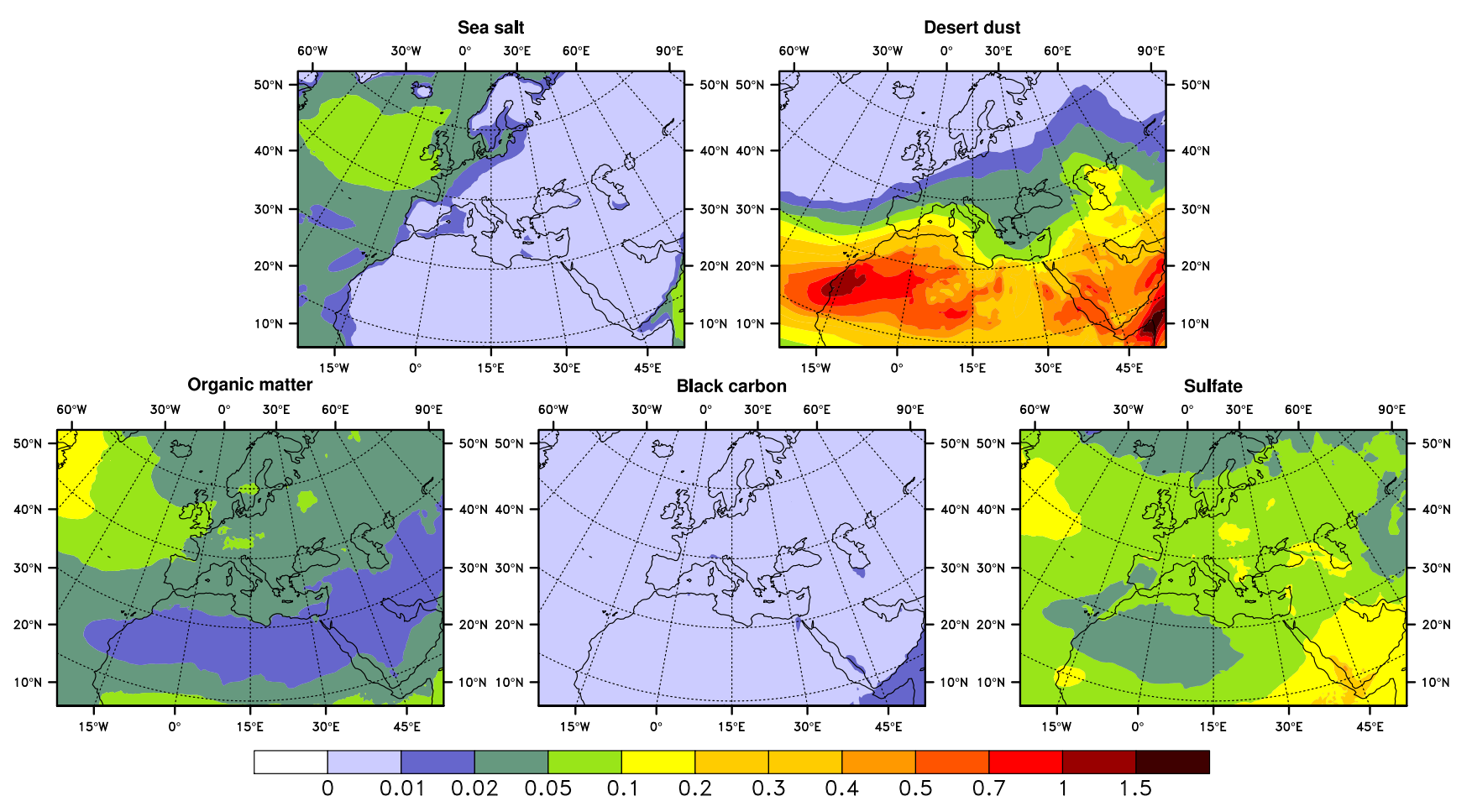

Figure 5. Mean aerosol optical depth at $550 \mathrm{~nm}$ in summer 2012 (JJA) simulated by CNRM-RCSM5 for the five aerosol types (sea salt, desert dust, organic matter, black carbon and sulphate).
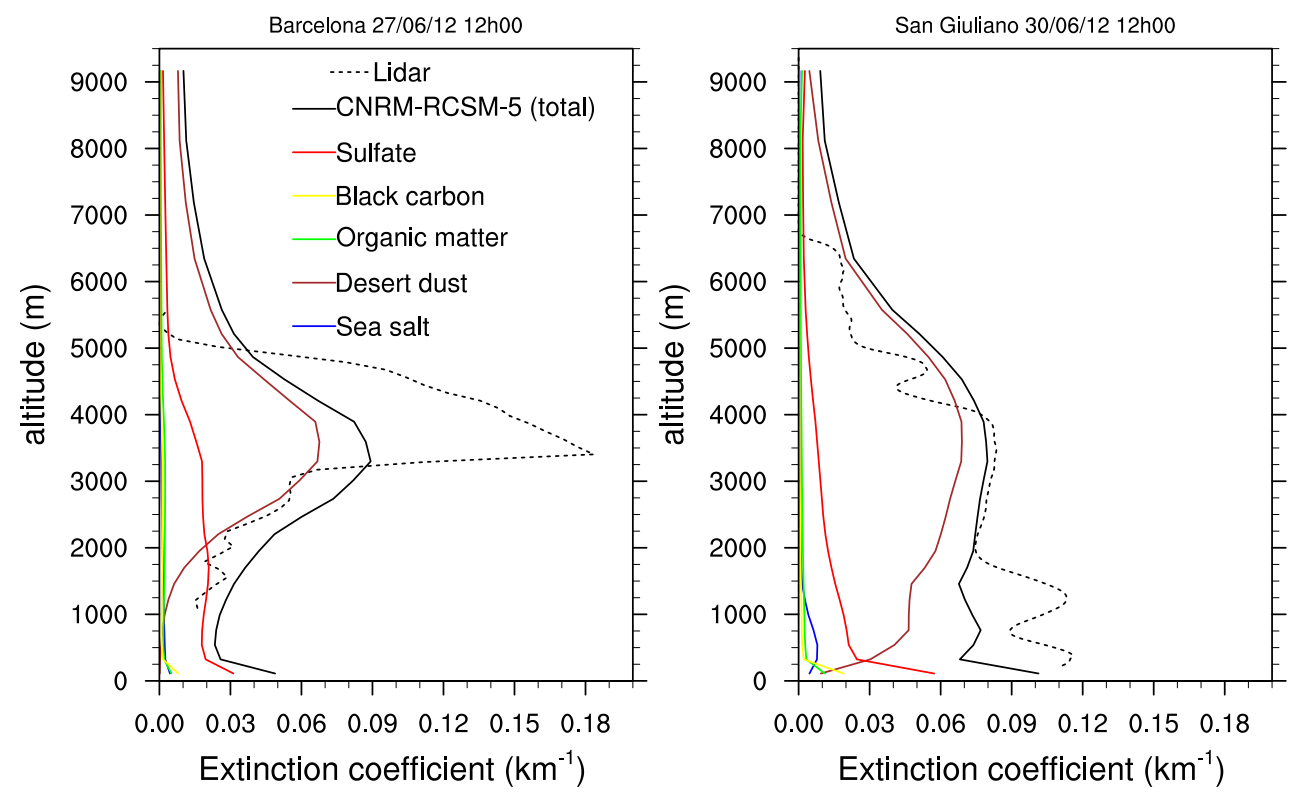

Figure 6. Aerosol extinction coefficient simulated by CNRM-RCSM5 (full black lines) and observed by a ground-based lidar (dotted black lines) in Barcelona on 27 June at 12:00 UTC (left) and in San Giuliano (Corsica) on 30 June 2012 at 12:00 UTC (right). The different coloured lines represent the contribution of each aerosol type to the extinction coefficient. 

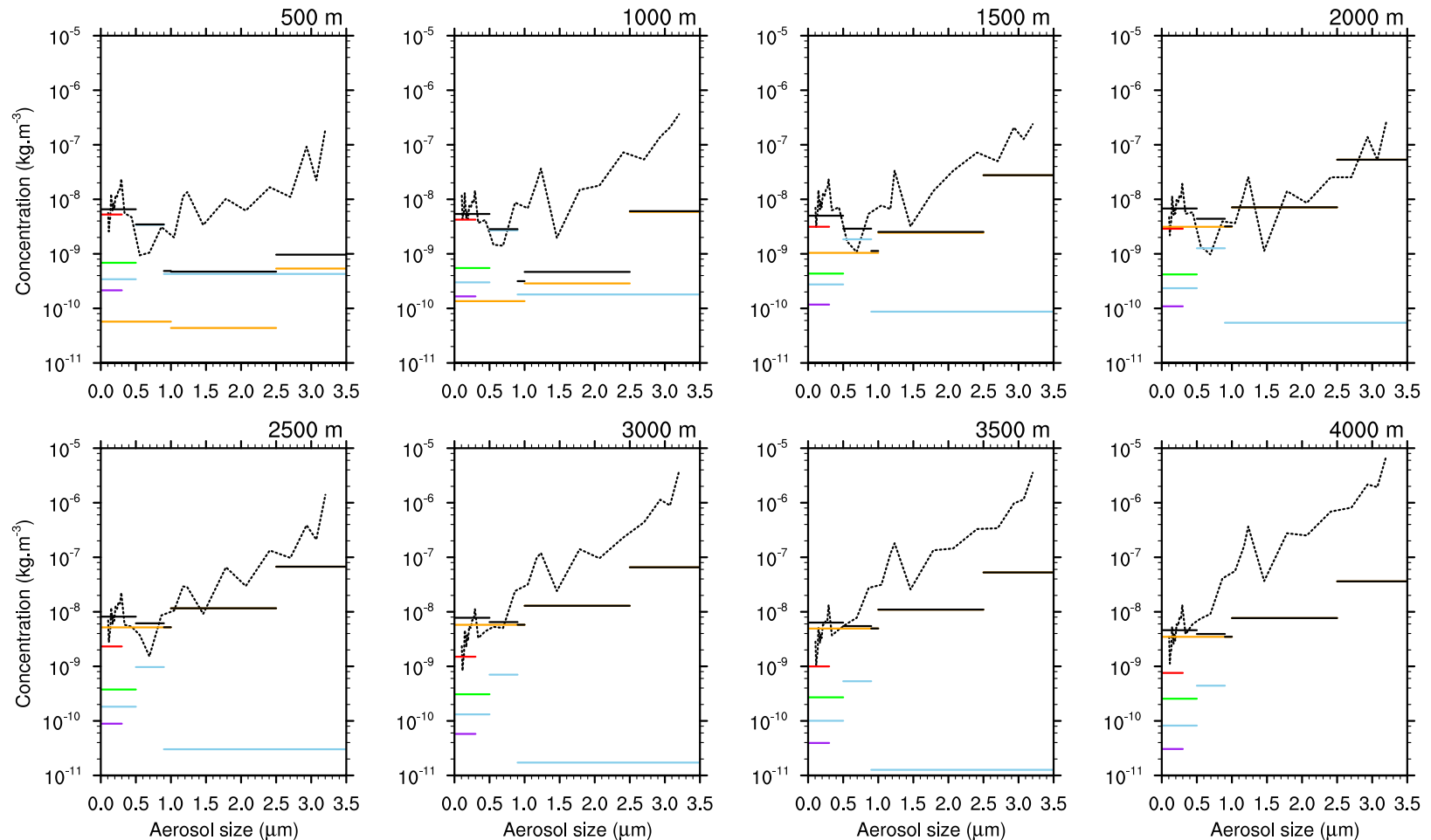

Figure 7. Dust particle size distribution observed by the PCASP instrument onboard ATR42 (flight 22) on 29 June at 08:00 UTC (dashed black lines), the dust refractive index has been adjusted (1.53-0.002i). Full coloured lines indicate the aerosol concentration for each aerosol bin of CNRM-RCSM5 (red is sulphate, blue is sea salt, orange is dust, green is organic matter and purple is black carbon), while full black lines indicate the total concentration $\left(\mathrm{kg} \mathrm{m}^{-3}\right)$.

mass concentration is higher for larger particles, especially between 2000 and $4000 \mathrm{~m}$, where dust aerosols are located. This distribution is simulated by CNRM-RCSM5, notably between 2000 and $3000 \mathrm{~m}$. Above $3000 \mathrm{~m}$, coarse particles (larger than $2.0 \mu \mathrm{m}$ ) are underestimated. However, these particles have less impact on extinction in $\mathrm{SW}$ radiation than submicronic particles, but they could play a role in other processes (e.g. deposition).

These results finally show that the aerosol vertical and size distributions simulated by CNRM-RCSM5 reproduce the main patterns seen in observations from the TRAQA campaign, even if the simulated profile in Barcelona shows an underestimated extinction peak between 3 and $5 \mathrm{~km}$ in altitude.

To summarize, we have shown in this section the strengths and the weaknesses of CNRM-RCSM5 to simulate the evolution of aerosols during summer 2012 in terms of spatial pattern and daily variability, as well as the vertical profiles and size distribution of dust particles. This model will be used in the following section to study the impact of dust outbreaks on meteorological parameters (radiation, temperature) in summer 2012. In addition, an intercomparison modelling study about this dust event observed in the TRAQA campaign will be the subject of a parallel study led by Sara Basart.

\section{Aerosol radiative effects}

As seen previously in the AOD temporal series, the Mediterranean basin has been affected by frequent dust outbreaks in summer 2012. This section aims at assessing their impact on different meteorological parameters.

\subsection{Direct radiative forcing (DRF)}

Figure 8 first shows the daily direct SW DRF of aerosols in PROG. DRF is calculated online during the simulation, calling twice the radiation code: with and without aerosols. A negative forcing of aerosols at the surface is noted. It is stronger over regions under dust influence - northern Africa, Arabian peninsula and the tropical Atlantic Ocean - reaching -20 to $-50 \mathrm{Wm}^{-2}$, in line with Nabat et al. (2015). Over Europe and the northern Atlantic, aerosol DRF ranges from -10 to $-15 \mathrm{Wm}^{-2}$ notably because of sulphate aerosols. Compared to estimations from literature such as the studies of di Sarra et al. (2008) and Di Biagio et al. (2010), who have found an average DRF of -30 and $-26 \mathrm{Wm}^{-2}$ respectively in Lampedusa, the values given by CNRM-RCSM5 have the same order of magnitude even if they can reach larger forcings. Also note that the Atlantic Ocean off Africa, under the influence of dust export, shows the highest variability. 

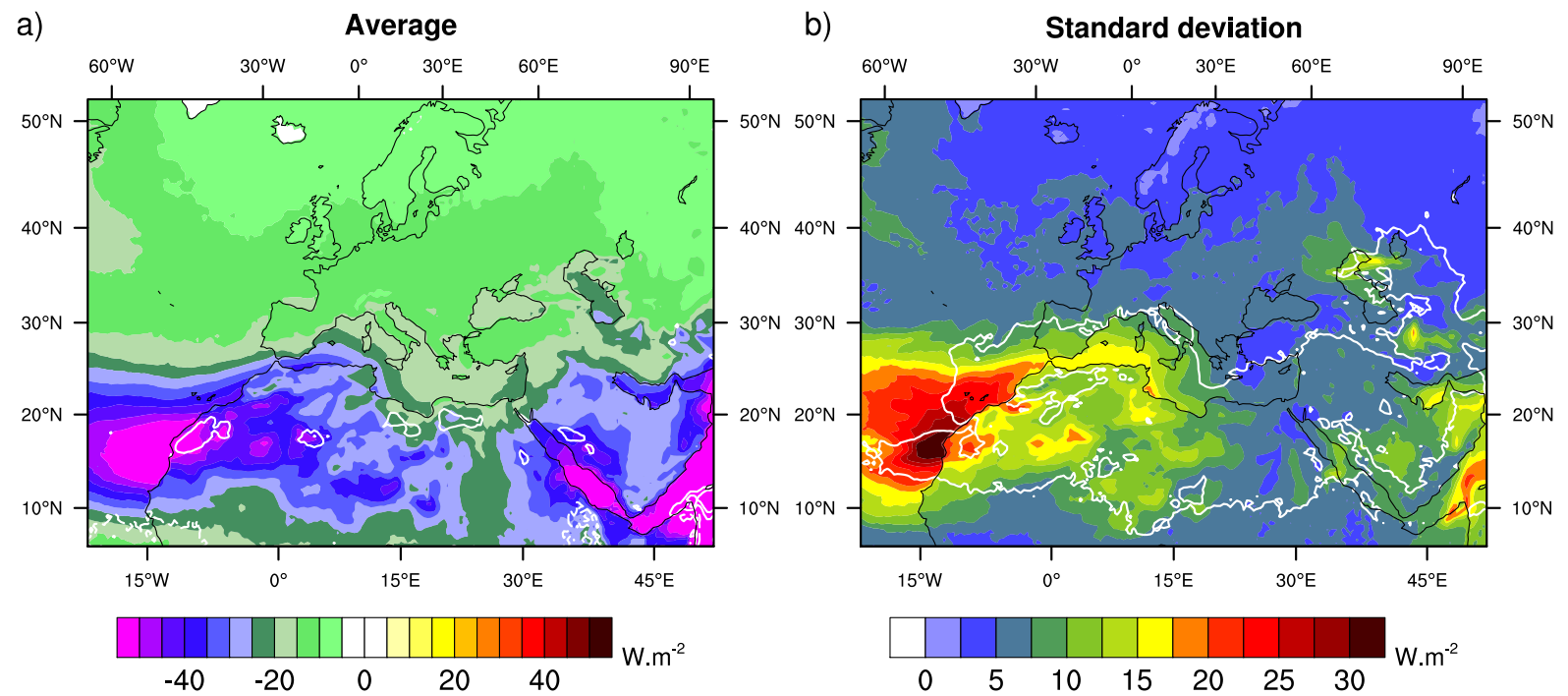

Figure 8. Aerosol SW direct radiative forcing (DRF): (a) Average in summer 2012 for PROG (colours) and the PROG-PROG-M difference (white lines, interval is $5 \mathrm{Wm}^{-2}$ ). (b) Standard deviation of daily DRF for PROG (colours). The white line indicated the region where the ratio between the standard deviations of PROG and PROG-M is higher than 2.

\subsection{At the daily scale}

As dust aerosols can interact with solar and thermal radiation, consequences on meteorological parameters such as surface radiation and temperature might be expected. In the present work, an effort has been made to gather colocalized measurements of AOD, SW radiation and $2 \mathrm{~m}$ temperature or sea surface temperature. The list of the 14 corresponding stations in the Mediterranean basin used in this study is presented in Table 1.

Daily series of solar surface radiation (SSR), cloud cover and surface temperature are presented in details for two stations representative of the Mediterranean basin, namely Lampedusa (LAM) and the buoy in the Gulf of Lions (LIO). Lampedusa is located in an island close to dust-emitting regions where clear-sky conditions are frequent in summer, while LIO is in the northwestern Mediterranean, where more clouds are observed. Figures 9 and 10 present respectively in LAM and in LIO the daily series of AOD, downward SSR, cloud cover and surface temperature ( $2 \mathrm{~m}$ temperature and SST respectively), observed and simulated by PROG, PROG-M and NO.

First of all, NO is the only CNRM-RCSM5 simulation to have a high bias against observed SSR $\left(+18.0 \mathrm{Wm}^{-2}\right.$ in LAM, $31.2 \mathrm{Wm}^{-2}$ in LIO) compared to PROG-M $\left(-6.0 \mathrm{Wm}^{-2}\right.$ in LAM, $13.6 \mathrm{Wm}^{-2}$ in LIO) and PROG $\left(-3.5 \mathrm{Wm}^{-2}, 15.9 \mathrm{Wm}^{-2}\right.$ in LIO) due to the absence of aerosols in NO. While the aerosol climatology is enough to reduce the bias in PROG-M, PROG has the highest temporal correlation (0.87 against 0.81 for NO and 0.85 for PROG-M in LAM), and its standard deviation is the closest to observations (a ratio of 0.88 against 0.74 both for $\mathrm{NO}$ and PROG-
$\mathrm{M}$ in LAM). Indeed, PROG-M and NO clearly miss some variations of SSR. When AOD is high (e.g. 21/06, 3-12/07, 29/07, 7/08 in LAM, 19/06, 27/07, 20/08 in LIO), PROG-M and NO overestimate SSR, especially in case of low cloud cover. Inversely when AOD is low (e.g. 24/06, 20/07, 10/08 in LAM, 5/06, 27/08 in LIO), PROG-M underestimates SSR while NO benefits in this case from the absence of aerosols. ERA-Interim has a monthly aerosol climatology similar to PROG-M except that the aerosol climatology used in ERAInterim (Tegen et al., 1997) is probably less realistic and simulates radiation variations lower than observed. As a result, the effect of aerosols on surface radiation has been identified in both stations.

With regards to land surface temperature in LAM and SST in LIO, the three CNRM-RCSM5 simulations have similar temporal correlations (between 0.72 and 0.73 for LAM, 0.98 for SST in LIO), while PROG-M and PROG are on average cooler than NO because of the aerosol forcing. Even during dust outbreaks, it is not possible to state that average temperature in PROG is closer to observations. With regards to standard deviations, the daily variability is reduced in PROG (0.89 in LAM against 0.92 for PROG-M and 0.95 for NO). The aerosol forcing during dust events could indeed decrease the maximum daily temperature, while the effect of dust particles on thermal surface radiation (TSR) could increase night-time temperature and thus reduce $\mathrm{T} 2 \mathrm{~m}$ diurnal variability.

In order to confirm these results in the other stations, the evaluation of surface radiation and $2 \mathrm{~m}$ temperature for the three simulations and the ERA-Interim reanalysis in the 14 stations is presented respectively in Tables 4 and 5. As far as radiation is concerned, the bias is reduced both in PROG and 


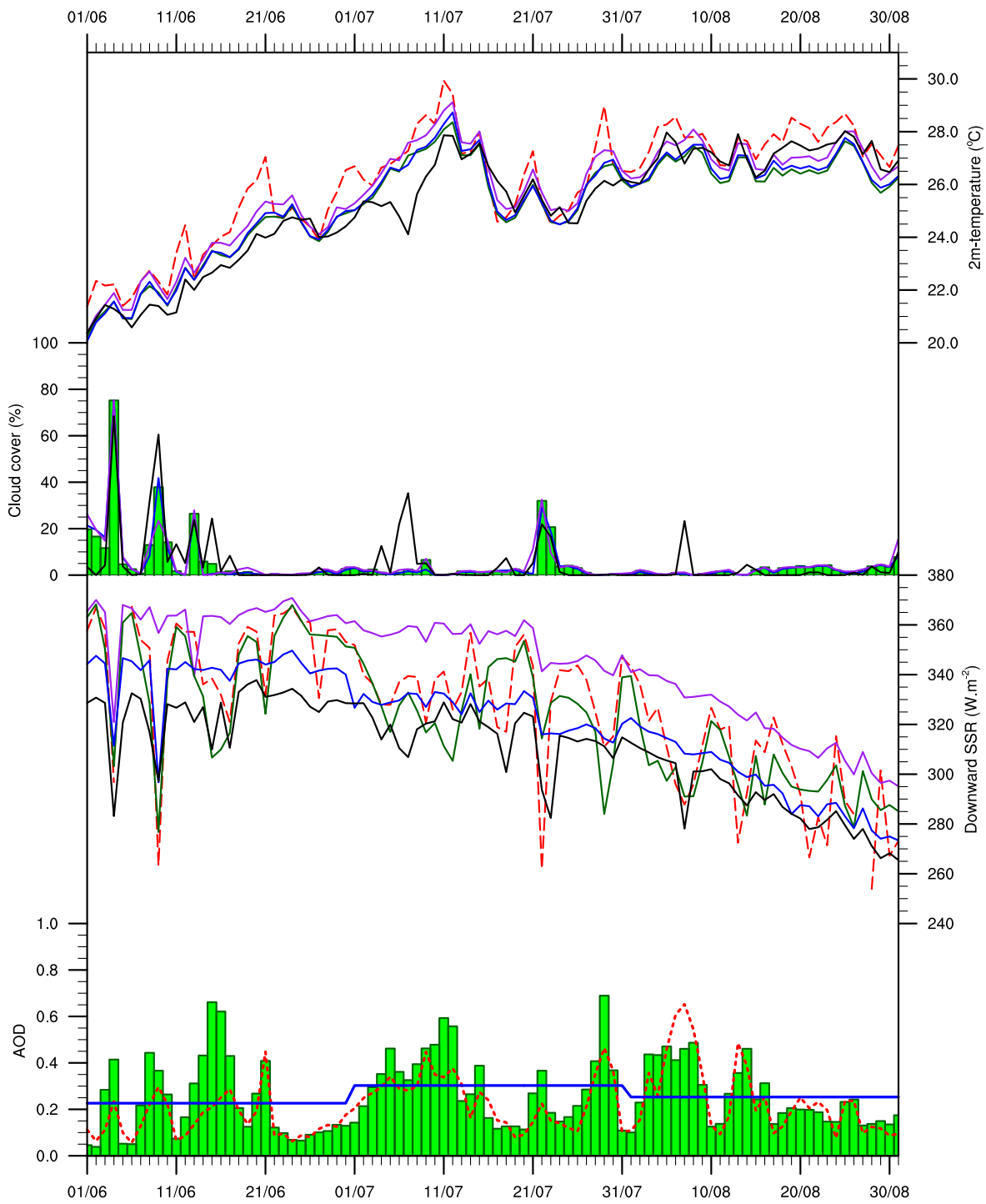

Figure 9. Cloud cover (\%, green bars for PROG, curves for the other simulations), $2 \mathrm{~m}$ temperature $\left({ }^{\circ} \mathrm{C}\right.$, curves), cloud cover $(\%$, green bars for PROG, curves for the other simulations), downward SSR $\left(\mathrm{Wm}^{-2}\right.$, curves) and AOD (green bars for PROG, blue line for PROG-M), from top to bottom, in Lampedusa (Italy) for PROG (green), PROG-M (blue), NO (purple), ERA-Interim (black) and observations (dashed red).

PROG-M, reaching a level close to ERA-Interim (between 11 and $13 \mathrm{Wm}^{-2}$ ). A net improvement is noted in temporal correlation, since it is higher in PROG than in PROG-M and NO in every station. Daily variability in SSR is also higher in PROG for most stations, representing an improvement compared to observations except where this variability was already overestimated (e.g. Ajaccio). It is worth mentioning that in Sde Boker PROG gets closer to observations by reducing SSR variability. A misrepresentation of cloud processes could also explain some of the discrepancies with observations. The lack of cloud cover in CNRM-RCSM shown in Nabat et al. (2015) could explain the remaining bias. ERAInterim, which does not have the daily aerosol variations and consequently misses some peaks in surface radiation, suc- ceeds in getting a high average correlation coefficient (0.79) probably because of a better representation of clouds. Moreover, changes in water vapour column amount may also affect the SSR to a lesser extent.

As far as surface temperature is concerned, no change in correlation coefficient is noted. The PROG simulation is cooler than NO and PROG-M, increasing the negative bias. Nevertheless the daily variability is slightly reduced, getting closer to observed variability. In addition, it is worth mentioning that ERA-Interim has the highest scores in terms of correlation and variability (standard deviation), probably benefiting from the assimilation of surface temperature (Dee et al., 2011). 


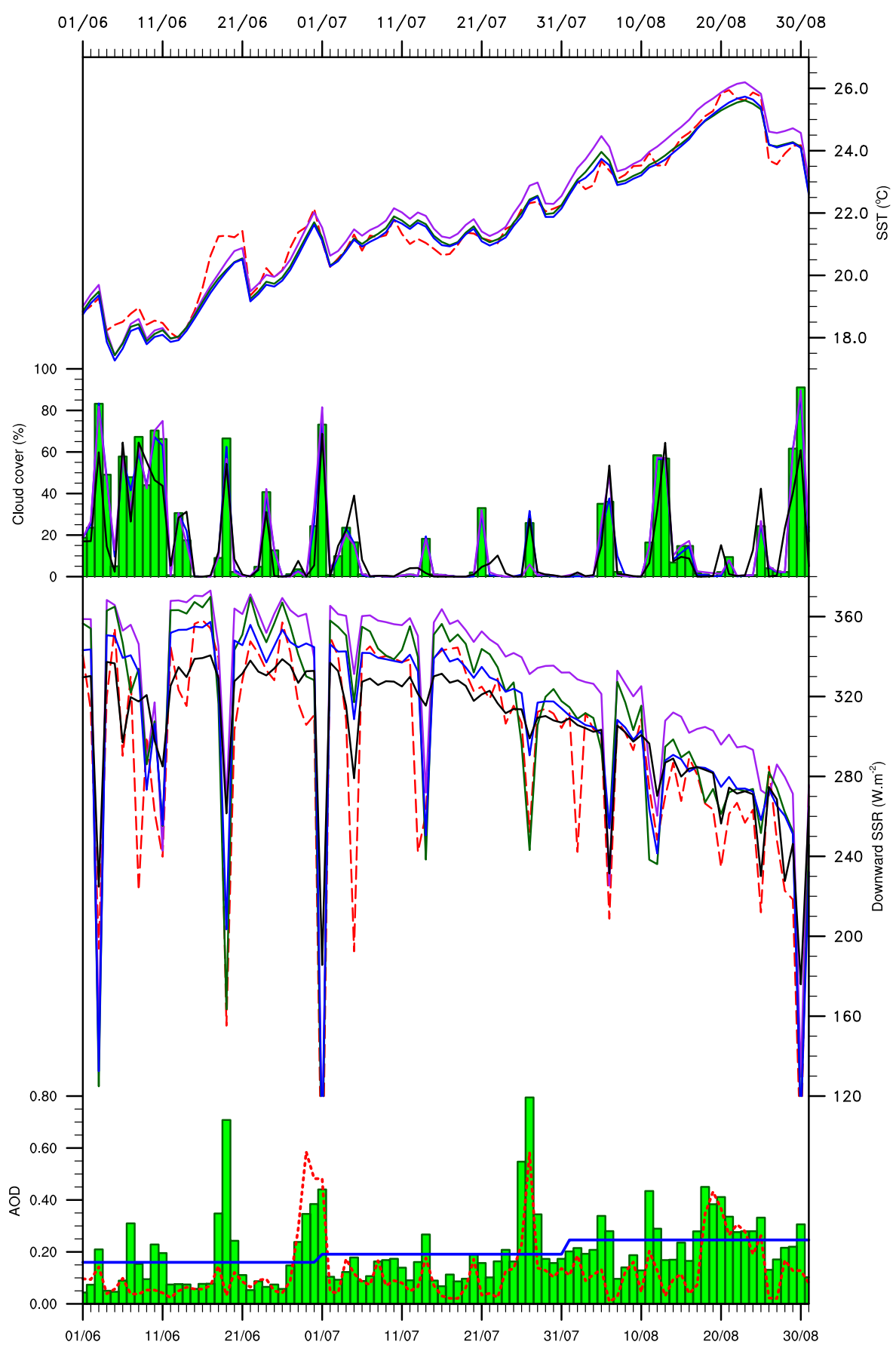

Figure 10. Same as Fig. 9 but for the buoy in the Gulf of Lions (LIO) and SST instead of $2 \mathrm{~m}$ temperature.

As a result, these comparisons show that the prognostic aerosol scheme used in PROG enables the model to better reproduce the evolution of surface radiation, which cannot be done properly with an aerosol climatology. Besides, no improvement has been shown in the scores of land and sea surface temperature. However, aerosol maxima over the Mediterranean could be associated to particular weather conditions which are responsible for effects on radiation and temperature that are not due to aerosols. That is the reason why a composite study to isolate the effect of dust aerosols is carried out in the following section. 
Table 4. Evaluation of daily SSR simulated by NO, PROG-M, PROG and ERA-Interim against 14 ground-based measurements located around the Mediterranean basin, in terms of bias $\left(\mathrm{Wm}^{-2}\right)$, temporal correlation coefficient and standard deviation (SD) ratio.

\begin{tabular}{|c|c|c|c|c|c|c|c|c|c|c|c|c|c|c|c|}
\hline Bias & MUR & BAR & MAL & ALI & AJA & CAR & MON & NIC & PER & FES & LIO & AZU & LAM & SED & MOY \\
\hline NO & 31.0 & 2.8 & 54.3 & 39.0 & 18.0 & 22.3 & 35.9 & 37.6 & 34.7 & 48.2 & 31.2 & 35.1 & 18.0 & 5.6 & 29.6 \\
\hline PROG-M & 7.6 & -8.5 & 35.1 & 18.1 & 2.4 & 10.1 & 20.8 & 19.6 & 19.3 & 13.6 & 13.6 & 16.6 & -6.0 & -13.4 & 10.6 \\
\hline PROG & 9.7 & -7.5 & 36.0 & 21.2 & 5.1 & 11.5 & 24.0 & 22.9 & 21.0 & 16.5 & 15.9 & 19.1 & -3.5 & -11.7 & 12.9 \\
\hline ERA-Interim & 12.8 & 4.6 & 53.7 & 25.4 & -1.0 & -4.3 & 17.0 & 10.1 & 27.7 & 34.7 & 10.2 & 7.2 & -16.8 & -12.9 & 12.0 \\
\hline \multicolumn{16}{|l|}{ Corr. } \\
\hline NO & 0.72 & 0.76 & 0.66 & 0.62 & 0.87 & 0.89 & 0.71 & 0.67 & 0.76 & 0.39 & 0.87 & 0.86 & 0.81 & 0.84 & 0.75 \\
\hline PROG-M & 0.76 & 0.77 & 0.65 & 0.67 & 0.89 & 0.87 & 0.70 & 0.69 & 0.77 & 0.49 & 0.88 & 0.87 & 0.85 & 0.89 & 0.76 \\
\hline PROG & 0.77 & 0.79 & 0.69 & 0.74 & 0.89 & 0.91 & 0.75 & 0.69 & 0.78 & 0.53 & 0.89 & 0.90 & 0.87 & 0.90 & 0.79 \\
\hline ERA-Interim & 0.79 & 0.81 & 0.88 & 0.81 & 0.88 & 0.88 & 0.77 & 0.68 & 0.75 & 0.37 & 0.90 & 0.76 & 0.87 & 0.88 & 0.79 \\
\hline \multicolumn{16}{|l|}{$\mathrm{SD}$} \\
\hline NO & 0.79 & 1.20 & 0.84 & 1.16 & 1.11 & 0.96 & 0.97 & 0.81 & 0.96 & 0.93 & 0.92 & 1.00 & 0.74 & 1.15 & 0.97 \\
\hline PROG-M & 0.79 & 1.10 & 0.82 & 1.11 & 1.10 & 0.86 & 0.92 & 0.81 & 0.93 & 0.94 & 0.91 & 1.04 & 0.74 & 0.99 & 0.93 \\
\hline PROG & 0.95 & 1.16 & 1.01 & 1.20 & 1.17 & 0.94 & 0.98 & 0.88 & 0.99 & 1.01 & 1.01 & 1.12 & 0.88 & 1.07 & 1.03 \\
\hline ERA-Interim & 0.58 & 0.72 & 0.69 & 0.78 & 0.78 & 0.77 & 0.69 & 0.72 & 0.63 & 0.53 & 0.61 & 0.90 & 0.67 & 0.92 & 0.71 \\
\hline
\end{tabular}

Table 5. Evaluation of daily $2 \mathrm{~m}$ temperature simulated by NO, PROG-M, PROG and ERA-Interim against 13 ground-based measurements located around the Mediterranean basin, in terms of bias $\left({ }^{\circ} \mathrm{C}\right)$, temporal correlation coefficient and standard deviation (SD) ratio.

\begin{tabular}{lrrrrrrrrrrrrrr}
\hline Bias & MUR & BAR & MAL & ALI & AJA & CAR & MON & NIC & PER & FES & LIO & AZU & LAM & MOY \\
\hline NO & 0.3 & -1.6 & 1.2 & -0.5 & -1.5 & 0.9 & -1.5 & -0.0 & -2.0 & 0.0 & 0.6 & 1.6 & -0.4 & -0.3 \\
PROG-M & -0.6 & -1.7 & 0.8 & -0.7 & -1.7 & 0.8 & -1.7 & -0.3 & -2.2 & -0.4 & 0.4 & 1.4 & -0.8 & -0.5 \\
PROG & -0.8 & -1.9 & 0.7 & -0.8 & -1.8 & 0.8 & -1.7 & -0.3 & -2.2 & -0.4 & 0.4 & 1.4 & -0.8 & -0.6 \\
ERA-Interim & -2.7 & -2.8 & -1.2 & -0.1 & 0.1 & -2.8 & -1.3 & -1.4 & -1.6 & -0.9 & 0.4 & 0.6 & -0.5 & -1.1 \\
\hline Corr. & & & & & & & & & & & & & \\
\hline NO & 0.76 & 0.87 & 0.91 & 0.76 & 0.88 & 0.92 & 0.77 & 0.79 & 0.87 & 0.91 & 0.97 & 0.82 & 0.96 & 0.86 \\
PROG-M & 0.77 & 0.89 & 0.92 & 0.77 & 0.88 & 0.92 & 0.77 & 0.81 & 0.88 & 0.92 & 0.97 & 0.81 & 0.96 & 0.86 \\
PROG & 0.76 & 0.88 & 0.92 & 0.75 & 0.88 & 0.92 & 0.77 & 0.80 & 0.89 & 0.92 & 0.97 & 0.81 & 0.96 & 0.86 \\
ERA-Interim & 0.88 & 0.98 & 0.88 & 0.75 & 0.86 & 0.92 & 0.89 & 0.90 & 0.89 & 0.96 & 0.93 & 0.81 & 0.90 & 0.89 \\
\hline SD & & & & & & & & & & & & \\
\hline NO & 1.36 & 1.09 & 1.25 & 1.44 & 1.45 & 1.16 & 0.90 & 1.42 & 1.37 & 0.96 & 1.14 & 1.08 & 0.97 & 1.20 \\
PROG-M & 1.31 & 1.10 & 1.26 & 1.38 & 1.45 & 1.15 & 0.87 & 1.41 & 1.37 & 0.96 & 1.10 & 1.05 & 0.95 & 1.18 \\
PROG & 1.27 & 1.04 & 1.20 & 1.34 & 1.42 & 1.12 & 0.87 & 1.36 & 1.35 & 0.97 & 1.08 & 1.03 & 0.93 & 1.15 \\
ERA-Interim & 1.04 & 0.76 & 0.92 & 1.36 & 1.05 & 1.03 & 0.93 & 0.98 & 0.82 & 0.88 & 0.95 & 0.99 & 1.00 & 0.98 \\
\hline
\end{tabular}

\subsection{Composite analysis}

\subsubsection{Methodology}

This section aims at highlighting the simulated and observed differences between days of high aerosol load and the set of all the days in terms of several meteorological parameters (radiation, temperature, cloud cover, etc.). For the 14 stations defined previously, the days of high AOD, called thereafter "dusty" days as dust aerosols are mostly responsible for these AOD maxima, have been selected over the 92 days of summer 2012 (June-July-August). A day is considered as a dusty day provided that observed AOD is higher than 0.2 and that simulated dust AOD in PROG is higher than 0.2. Days when observations were not available have been removed.

Average differences for several parameters have then been calculated between the dusty days and the set of all the days for the three simulations (NO, PROG-M and PROG) and observations. The differences obtained for NO will enable us to estimate the meteorological effect due only to changes in weather parameters (cloud cover, wind, etc.) without considering the aerosols; those for PROG-M can estimate the average effect of having an aerosol climatology; and those for PROG can estimate the added value of prognostic aerosols. The objective is to isolate the effects of aerosols from weather changes that are systematically observed dur- 
ing dust outbreaks. This method is first presented for the station of Murcia, whose results are representative of the whole Mediterranean basin, and then generalized to the 14 stations.

\subsubsection{Case of Murcia}

In Murcia, 23 days have been identified as dusty days over the 83 days when observations are available; results are presented in Table 6. First of all, as expected, the difference in AOD between dusty days and the set of all the days is clearly positive in the PROG simulation (0.19), very low in PROG-M (-0.01) but not necessarily zero, because the number of dusty days varies from 1 month to another (AOD is monthly constant in PROG-M), and equal to zero in NO (no aerosols). This difference in AOD is similar in the observations and PROG, confirming the ability of CNRM-RCSM5 to reproduce aerosol daily variability and making the comparison for other parameters possible. The higher AOD during dusty days leads to a decrease in downward SSR. The difference with the set of all the days reaches $-22 \mathrm{Wm}^{-2}$ against only -6 and $-7 \mathrm{Wm}^{-2}$ for NO and PROG-M respectively, while measurements in the station show a difference of $-19 \mathrm{Wm}^{-2}$. The difference in NO $\left(-6 \mathrm{Wm}^{-2}\right)$ can be considered as the "weather effect" that is due to the choice of the days (meteorological and astronomical variations). The duration of sunshine indeed varies during summer and reaches its maximum at the solstice (21 June), which can explain a part of the radiation differences in NO, in addition to changes in cloud cover. PROG-M, which has a monthly climatology of aerosols, is useful to identify changes in atmospheric circulation and cloud cover due to a monthly climatology of aerosols $\left(-1 \mathrm{Wm}^{-2}\right)$. The difference between PROG-M and PROG gives the contribution of the daily variability of aerosols that is necessary to reproduce observed radiation measurements. Few changes among the three simulations are observed in cloud cover and TSR.

Temperature is also affected by weather changes, as dusty days are $1.6^{\circ} \mathrm{C}$ higher in $\mathrm{NO}$ than the set of all the days. This is probably explained by the predominance of stronger southern fluxes during dusty days that can transport aerosols from Sahara to the Mediterranean basin. Figure 11 indeed shows the average circulation at $850 \mathrm{hPa}$ during dusty days and the set of all the days, indicating a reinforcement of south-westerly winds in southern Spain advecting warm air. However, this increase in temperature during dusty days is lower in PROG than in PROG-M and NO, which is closer to observed variations of temperature. This decrease of $-0.2^{\circ} \mathrm{C}$ between PROG-M and PROG is caused by dust aerosols that have reduced incoming solar radiation. In other words, without prognostic aerosols the warming simulated by CNRMRCSM during dusty days is too strong compared to observations, which is corrected in PROG. A similar impact is observed in soil temperature.

As a result, radiation and temperature in Murcia have been shown to be better reproduced in the PROG simulation, showing the added value of a prognostic scheme compared to monthly climatologies to reproduce local meteorological variations.

\subsubsection{Generalization}

A similar composite study has been carried out for other stations (defined in Table 1) where daily radiation and temperature data were available. Figure 12 presents the results per station for six parameters (AOD, solar and thermal surface radiation, cloud cover, $2 \mathrm{~m}$ and soil temperature) for the NO, PROG-M and PROG simulations, as well as for observations when available, while the average composites are given in Table 7.

As in Murcia, the difference in AOD between dusty days and the set of all the days is for every station similar in observations (0.22 on average) and the PROG simulation (0.21). The difference in PROG-M comes only from the number of dusty days varying from 1 month to another. As a consequence, measurements reveal that downward SSR is on average $23 \mathrm{Wm}^{-2}$ lower during dusty days, which is correctly reproduced by PROG $\left(-23 \mathrm{Wm}^{-2}\right)$. A part of this decrease $\left(-2 \mathrm{Wm}^{-2}\right)$ is explained by weather changes as simulated by NO, while added an aerosol climatology does not bring significant differences $\left(-3 \mathrm{Wm}^{-2}\right)$. Additionally, the decrease of SSR in dusty days varies from one station to another (ranging from -2 to $-53 \mathrm{Wm}^{-2}$ ). The amplitude of the increase in AOD on dusty days and changes in weather conditions explain this variability. For example in Mallorca, an increase of $6 \%$ in cloud cover on dusty days amplifies the dimming due to aerosol loads.

With regards to downward TSR, an average increase of $14 \mathrm{Wm}^{-2}$ is simulated by PROG on dusty days, but it is mainly due to weather conditions as NO and PROG-M also show an increase of $12 \mathrm{Wm}^{-2}$. Dust aerosols would consequently only represent an increase of $2 \mathrm{Wm}^{-2}$. Unfortunately, few LW observations are available. The measurements in the Gulf of Lions and in Lampedusa show a lower increase than the simulations.

More observations are available for $\mathrm{T} 2 \mathrm{~m}$, revealing a general increase of temperature on dusty days (on average $\left.1.4{ }^{\circ} \mathrm{C}\right)$. As in Murcia, this increase is probably due to warm advection caused by southerly to south-westerly winds responsible of these dust outbreaks. NO indeed simulates an average increase of $1.7^{\circ} \mathrm{C}$ but reduced to $1.5^{\circ} \mathrm{C}$ in PROG, indicating the cooling due to dust aerosols, which makes the simulation closer to observations. This improvement is noted in 10 out of the 13 stations considered in the study (Fig. 12) these 10 stations being the 9 continental stations and the buoy Azur. The other stations either do not show a cooling (Ajaccio) or this cooling is not in line with observations (buoy of the Gulf of Lions, Lampedusa). For these two latter stations, sea surface temperature also increases on dusty days (up to $2.0^{\circ} \mathrm{C}$ in the Gulf of Lions in NO), while PROG-M and PROG both alleviate this increase by $0.1{ }^{\circ} \mathrm{C}$. However, 
Table 6. Composite study for Murcia: differences between dusty days and the set of all the days in observations (OBS), NO, PROG-M and PROG for AOD, downward SSR $\left(\mathrm{Wm}^{-2}\right)$, cloud cover $(\%)$, downward TSR $\left(\mathrm{Wm}^{-2}\right), 2 \mathrm{~m}$ temperature $\left({ }^{\circ} \mathrm{C}\right)$ and soil temperature $\left(\mathrm{Ts},{ }^{\circ} \mathrm{C}\right)$. The contribution of the different effects, namely weather, aerosol (mean) and aerosol (variability), have been added.

\begin{tabular}{lrrrrrrr}
\hline Parameter & OBS & NO & PROG-M & PROG & Weather & Aerosol (mean) & Aerosol (var) \\
\hline AOD & 0.15 & 0.00 & -0.01 & 0.19 & 0.00 & -0.01 & 0.20 \\
SSR & -19 & -6 & -7 & -22 & -6 & -1 & -15 \\
Cloud cover & - & 1 & 2 & 1 & 1 & 1 & -1 \\
TSR & - & 10 & 9 & 11 & 10 & -1 & 2 \\
T2m & 1.2 & 1.6 & 1.5 & 1.3 & 1.6 & -0.1 & -0.2 \\
Ts & - & 1.5 & 1.4 & 1.2 & 1.5 & -0.1 & -0.2 \\
\hline
\end{tabular}

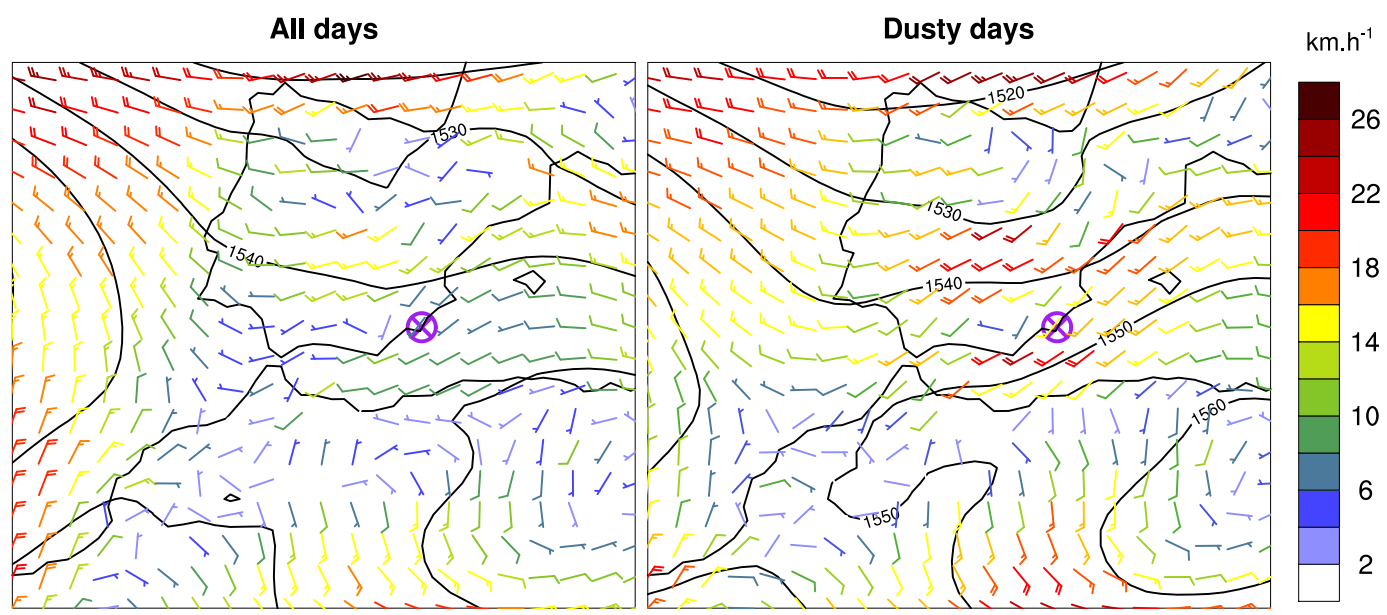

Figure 11. Average wind ( $\mathrm{km} \mathrm{h}^{-1}$, coloured barbs) and geopotential (mgp, black lines) at $850 \mathrm{hPa}$ for the set of all the days (left) and the dusty days (right) defined in Murcia (purple cross).

this reduction cannot be confirmed by observations. Maybe the 3-month period is not long enough to identify the daily effects of aerosols on SST. With regards to land soil temperature, a cooling of $-0.3^{\circ} \mathrm{C}$ due to dust aerosols is simulated by PROG, in relationship with the cooling in $\mathrm{T} 2 \mathrm{~m}$.

In fact, this composite analysis has shown that significant differences are observed between dusty days and the set of all the days, which come both from weather changes (notably due to south-westerly winds bringing warm air) and from the presence of dust aerosols that alleviate this warming by reducing incoming solar radiation. These results underline the importance of the use of prognostic aerosols to represent daily variations in weather parameters such as temperature and radiation.

\subsection{Impact of daily aerosol variability on the summer average}

The question that arises from the impact of aerosols shown on surface radiation and temperature during dusty days is whether using an aerosol prognostic scheme instead of a monthly climatology also has an impact on the summer average.
As far as DRF is concerned, average differences in summer 2012 between PROG and PROG-M are presented in Fig. 13 both for SW (a) and LW (b) radiation. The intensity of the average aerosol forcing is slightly lower $\left(3 \mathrm{Wm}^{-2}\right)$ in PROG-M than in PROG for the SW component, while very few differences are observed for LW radiation. Moreover, the daily standard deviation of SW DRF is higher in PROG than in PROG-M, particularly over northern Africa and the Mediterranean Sea, where it is more than twice as high (Fig. 8b). Indeed, dust emission is not a continuous phenomenon, because it is associated with episodes of strong wind over northern Africa. Consequently, dust particles show high variability over the Mediterranean basin that PROG-M cannot take into account, contrary to PROG. The only daily variations of DRF in PROG-M are due to cloud cover variations, as the aerosol effect can be partially masked by the presence of clouds.

As a consequence, the aerosol effect on surface temperature is on average slightly different in PROG-M compared to PROG (Fig. 13c). The general cooling, due to the presence of aerosols that scatter and absorb incident solar radiation, preventing it from reaching the surface, is either reinforced (e.g. in the south-western Mediterranean) or alleviated (e.g. 
a)

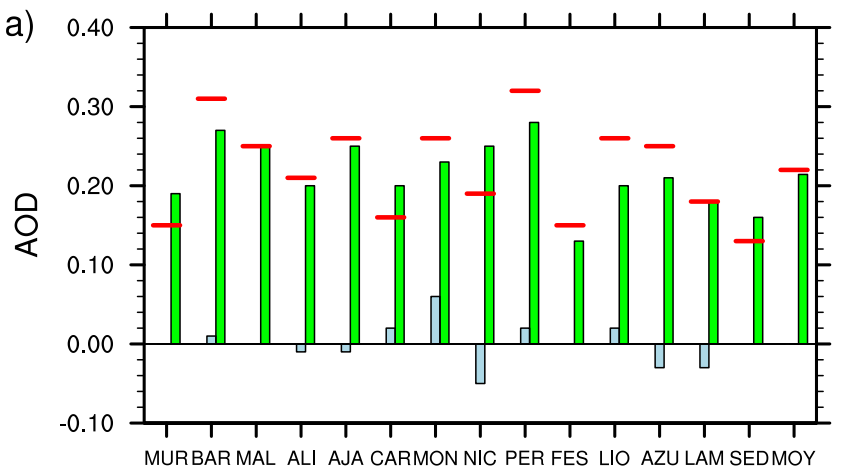

c)

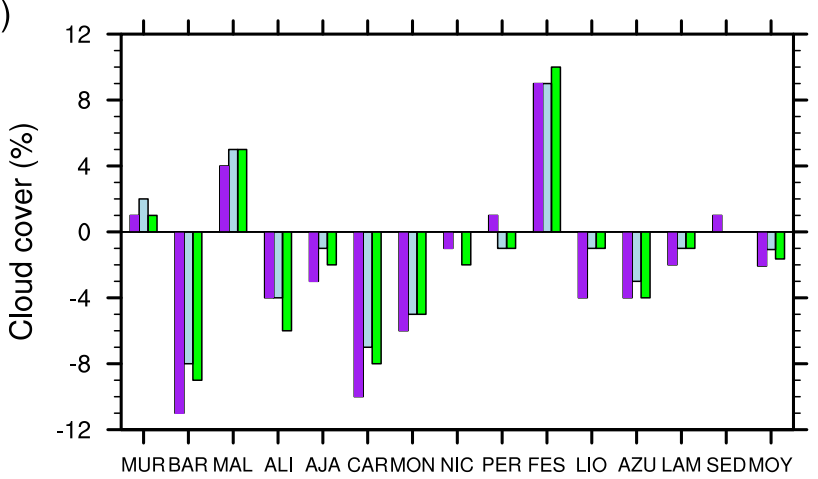

e)

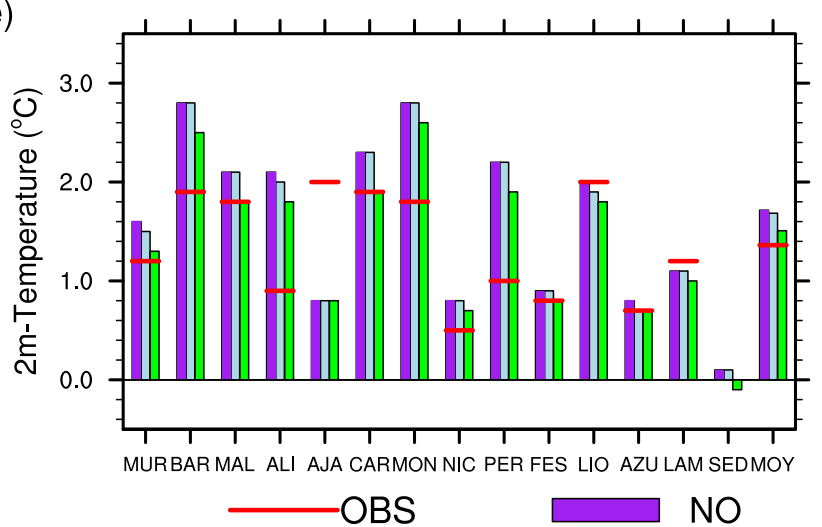

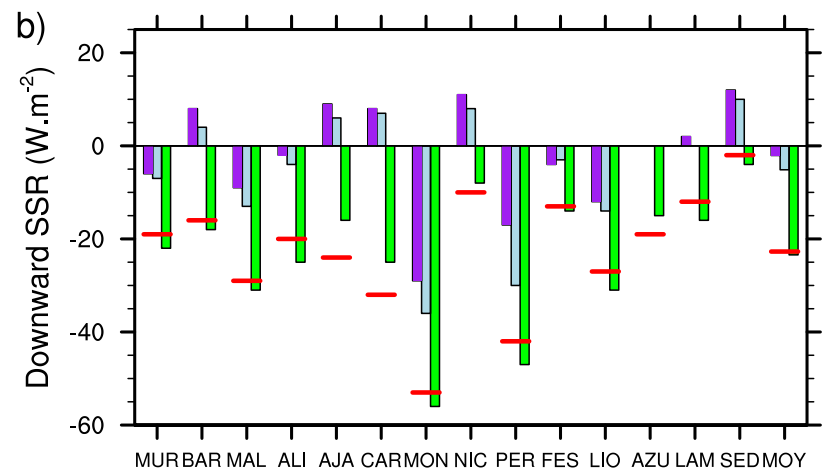

d)

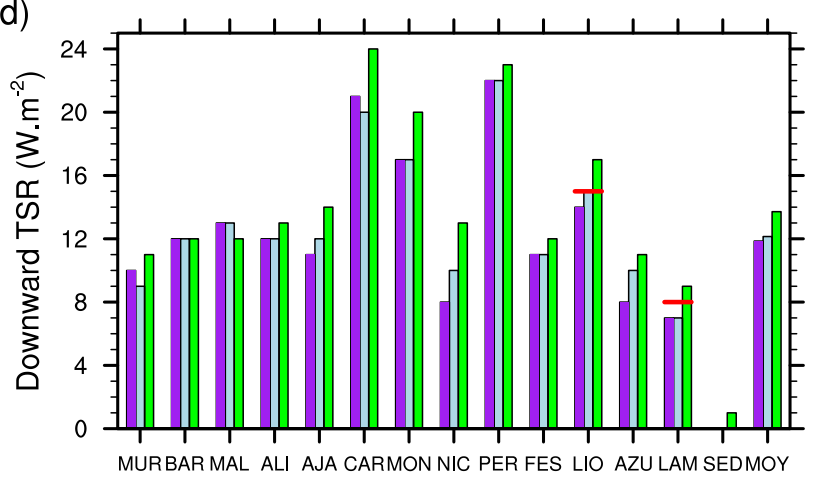

f)

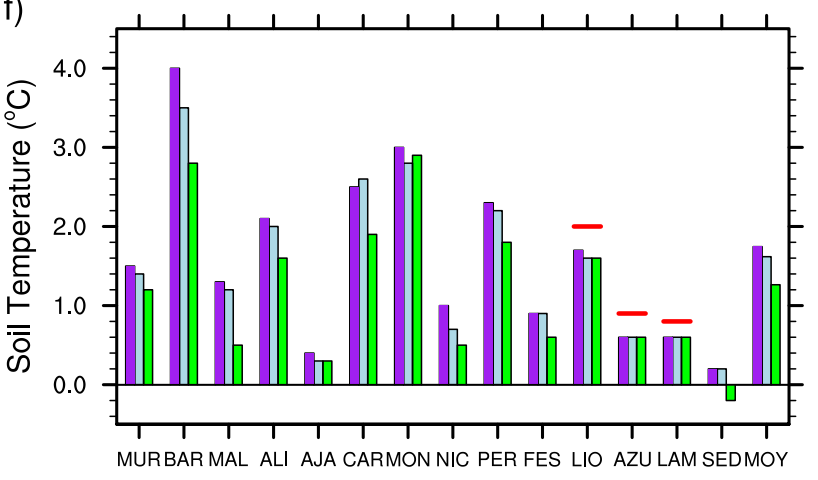

PROG-M

PROG

Figure 12. Average AOD (a), downward SSR (b), cloud cover (c), downward TSR (d), $2 \mathrm{~m}$ temperature (e) and soil temperature (f) differences between the dusty and the set of all the days in 14 stations (presented in Table 1) in summer 2012 for the NO, PROG-M and PROG simulations, as well as observations (AERUS-GEO for AOD, ground-based measurements for the other parameters). For Lampedusa and the buoys in the Gulf of Lions and Azur, $2 \mathrm{~m}$ temperature has been replaced by SST.

Table 7. Same as Table 6 but for the average over the 14 stations defined in Table 1.

\begin{tabular}{lrrrrrrr}
\hline Parameter & OBS & NO & PROG-M & PROG & Weather & Aerosol (mean) & Aerosol (var) \\
\hline AOD & 0.22 & 0.00 & 0.00 & 0.21 & 0.00 & 0.00 & 0.21 \\
SSR & -23 & -2 & -5 & -23 & -2 & -3 & -18 \\
Cloud cover & - & -2 & -1 & -2 & -2 & 1 & -1 \\
TSR & - & 12 & 12 & 14 & 12 & 0 & 2 \\
T2m & 1.4 & 1.7 & 1.7 & 1.5 & 2.0 & 0.0 & -0.2 \\
Land soil temperature & - & 1.7 & 1.6 & 1.3 & 1.7 & -0.1 & -0.3 \\
SST & 1.3 & 0.9 & 0.9 & 0.9 & 1.3 & 0.0 & 0.0 \\
\hline
\end{tabular}


a)
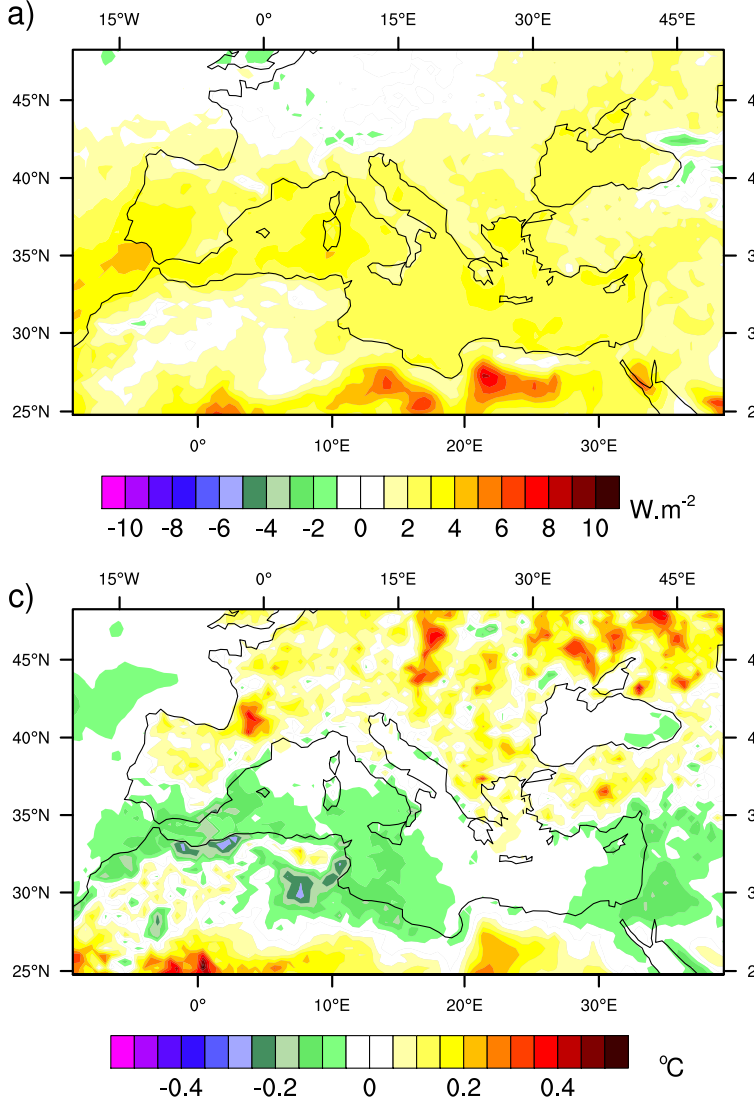

b)
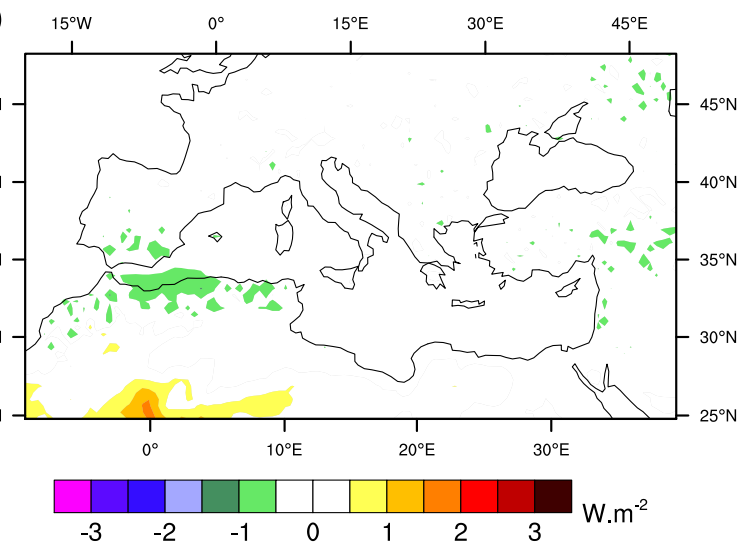

d)

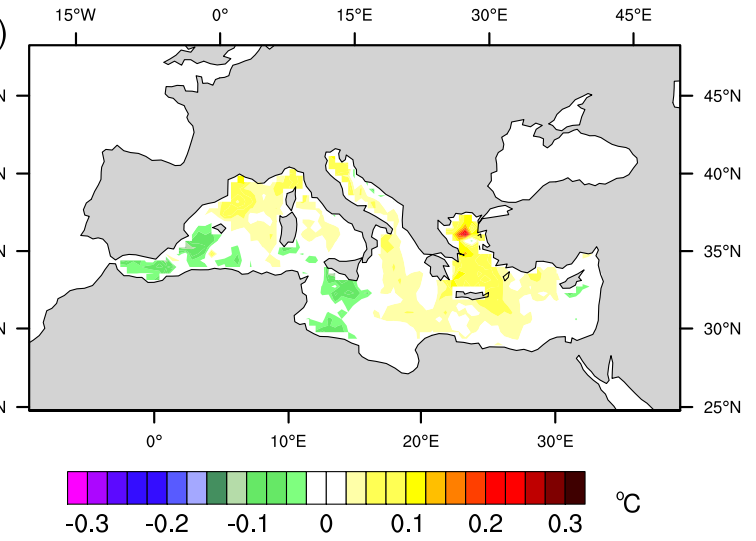

Figure 13. Average difference in summer 2012 between the PROG and PROG-M simulations in terms of (a) SW surface direct radiative forcing $\left(\mathrm{Wm}^{-2}\right)$, (b) LW surface direct radiative forcing $\left(\mathrm{Wm}^{-2}\right)$, (c) $2 \mathrm{~m}$ temperature $\left({ }^{\circ} \mathrm{C}\right)$ and $(\mathbf{d})$ sea surface temperature $\left({ }^{\circ} \mathrm{C}\right)$.

in eastern Europe) when using an aerosol interactive scheme instead of a monthly climatology. A similar difference between PROG and PROG-M is found for SST (Fig. 13d). These changes are probably due to the interactions between aerosols and weather conditions. As seen previously in the composite study, the fact that high dust loads often occur in southern fluxes could modify their impact on weather and climate. Moreover, when using an aerosol climatology, the variability of the atmospheric aerosol content is weaker, and the extreme values of AOD are not represented in the model.

Over the Mediterranean, while frequent AOD peaks are observed in the south-west due to frequent dust outbreaks, the latter less often reach the Gulf of Lions and hence there are less frequently AOD peaks there. The AOD standard deviation in PROG is, for example, 0.22 for the Strait of Gibraltar and only 0.14 for the Gulf of Lions. In addition, there are more days in the Strait of Gibraltar (32) where AOD is much higher (difference higher than 0.1) in PROG than in PROG$\mathrm{M}$ and in the Gulf of Lions (15), despite common averages. Consequently, the aerosol effect can be more important in the Strait of Gibraltar than in the Gulf of Lions, which must explain a cooler SST in the Strait of Gibraltar. In addition, the days when AOD is high in the Gulf of Lions are often cloudy, which alleviate the effect of aerosols. Indeed, dust outbreaks over the northern basins are more frequent under southerly winds (Gkikas et al., 2012) that also favour humidity advection and cloud cover.

In summary, the choice of using an aerosol prognostic scheme instead of a monthly climatology has not only an impact on daily weather and climate variability but also on the summer average. This second impact has never been shown before over the Mediterranean to our knowledge.

\subsection{Discussion}

This study has shown the radiative effects of dust aerosols in summer 2012 over the Mediterranean, but some points need to be discussed.

First, the choice to focus on a particular summer has been motivated by the fact that summer 2012 was particularly affected by dust outbreaks. Thus, a high number of dusty days were noted, providing an interesting case to estimate the radiative effects of dust aerosols. However, one can wonder if the results would change during a summer with few dust outbreaks, notably with regards to the impact of the choice of prognostic aerosols. As a matter of fact, the composite study and the analysis of the utility of prognostic aerosols should 
be redone for a longer period to better understand the interactions between dust aerosols and regional climate, even if finding adequate observations may represent an obstacle. It would be also interesting to consider the effects of dust aerosols during the other seasons.

In addition, the choice of using the spectral nudging method may have influenced the results, as it can be seen as a limitation of the effect of aerosols on the atmosphere. Indeed, this relaxation towards the ERA-Interim inside the regional domain could, for example, prevent aerosols from modifying temperature and humidity profiles above $700 \mathrm{hPa}$ and thus have stronger semi-direct effects. This point is particularly interesting with regards to the impact of the choice of prognostic aerosols instead of monthly AOD means. Nevertheless, the spectral nudging method is essential to represent the real chronology of dust events, making the comparison to observations possible. With regards to the uncertainties of the model outputs, they will be more deeply evaluated in a multimodel exercise currently carried out in the framework of the TRAQA/ChArMEx campaign.

Finally, the low complexity of the aerosol scheme used in the present work could constitute another limitation. In particular, the low number of bins for dust aerosols (only three), the absence of detailed processes representing the formation of secondary aerosols, the choice of a bulk approach for aerosol modelling and the absence of internal mixing are limitations to the present work. Future developments on this aerosol scheme will be carried out to improve the representation of aerosols in the model. For example, the implementation of the Ångstrom exponent will make the definition of dusty days for the composite study more robust. However, some of the simplifications remain necessary to keep a low numerical cost in order to be able to carry out easily multi-annual climate simulations with a coupling between the different components of the regional climate system (atmosphere, aerosols, land surface and ocean). Moreover, this scheme does not take into account the second indirect effect of aerosols because of the huge uncertainties in their parameterizations (Quaas et al., 2009).

\section{Conclusions}

A prognostic aerosol scheme has recently been added in the regional climate model ALADIN-Climate, enabling for the first time a regional coupled system model (CNRM-RCSM5) including the atmosphere, prognostic aerosols, land surface and the ocean components over the Mediterranean region. Simulations have been carried out in summer 2012, first to evaluate the aerosols produced by the model and then to estimate the radiative effects of dust outbreaks over the Mediterranean region.

CNRM-RCSM5 has shown its ability to reproduce the spatial and temporal variability of AOD over the Mediterranean region in summer 2012. The general spatial patterns, notably the locations of regions with high AOD, are in agreement with satellite data, while the distribution in the main different aerosol types is close to the MACC reanalysis and the independent climatology from Nabat et al. (2013). Daily variability is also correctly simulated by the model, since the evaluation against 30 stations from the AERONET network shows a mean bias of 0.02 , an average correlation coefficient of 0.70 and an average ratio of standard deviations of 1.01 as good as satellite data. In addition, the TRAQA campaign has provided lidar and airborne measurements of a strong dust outbreak that occurred at the end of June 2012. The aerosol vertical distributions observed in Barcelona and in Corsica show that the model is able to reproduce the altitude of maximum extinction, even when a slight overestimation has been noted in the upper troposphere. With regards to dust size distribution, the three-bin scheme used in ALADIN-Climate simulates higher mass concentrations for the largest particles, as well as a second maxima for submicronic particles, as observed during the TRAQA campaign.

The simulated aerosol surface SW DRF is negative, ranging from $-10 \mathrm{Wm}^{-2}$ in Europe to $-50 \mathrm{Wm}^{-2}$ in Africa, in line with previous studies. However, here the aerosol DRF is shown to have much variability when using a prognostic aerosol scheme instead of a monthly climatology. As a consequence, thanks to the prognostic aerosol scheme, downward SSR is better reproduced compared to ground-based measurements from several stations across the Mediterranean, both on days of high AOD (lower SSR) and low AOD (higher SSR), as correlation and standard deviation are improved. The forcing due to the dust outbreaks also causes extra cooling in surface temperature, but it is insufficient to improve significantly the correlation. However, the average difference between a simulation using a prognostic aerosol scheme and an aerosol climatology shows a cooling of 0.1 to $0.2^{\circ} \mathrm{C}$ both in T2m and SST close to the dust sources, notably in the south-western Mediterranean. Dynamics can also change in the two simulations and thus modify surface temperature.

A composite study has been realized in 14 stations across the Mediterranean to identify more precisely the differences between dusty days and the set of all the days. During dusty days, SSR is shown to be reduced on average by $28 \mathrm{Wm}^{-2}$ mostly because of the dimming of aerosols $\left(-17 \mathrm{Wm}^{-2}\right)$ but also because of weather conditions $\left(-10 \mathrm{Wm}^{-2}\right)$. In parallel, dust outbreaks that are responsible for dusty days also bring warm air, which explains why $\mathrm{T} 2 \mathrm{~m}$ is observed $1.6^{\circ} \mathrm{C}$ higher on dusty days. This warming is too strong $\left(2.0^{\circ} \mathrm{C}\right)$ when considering only an aerosol climatology. The prognostic scheme reduces this average warming of $0.2^{\circ} \mathrm{C}$, getting closer to observations.

Finally, this study has shown the improvement brought by a prognostic aerosol scheme compared to a monthly climatology in terms of radiation and temperature during a summer. This methodology could be applied on multi-annual simulations to evaluate the impact of prognostic aerosols at the climate scale. Differences could be expected not only in terms 
of variability but also in average climate as suggested by the differences shown in average SST in summer 2012 in the present work.

Acknowledgements. We would like to thank Météo-France for the financial support of the first author and the surface radiation and temperature in French stations. This work is part of the MedCORDEX initiative (www.medcordex.eu) and a contribution to the HyMeX and ChArMEx programmes. ChArMEx is the atmospheric component of the French multidisciplinary program MISTRALS (Mediterranean Integrated Studies aT Regional And Local Scales). ChArMEx-France was principally funded by INSU, ADEME, ANR, CNES, CTC (Corsica region), EU/FEDER, Météo-France and CEA. The aircraft was operated by SAFIRE. TRAQA was funded by ADEME/PRIMEQUAL and MISTRALS/ChArMEx programmes and Observatoire Midi-Pyrénées. This research has received funding from the French National Research Agency (ANR) projects ADRIMED (contract ANR-11-BS56-0006) and REMEMBER (contract ANR-12-SENV-0001) and MORDICUS (contract ANR-13-SENV-0002), as well as from the FP7 European Commission project CLIMRUN (contract FP7-ENV-2010-265192). The authors acknowledge AEMET for supplying the data and the HyMeX database teams (ESPRI/IPSL and SEDOO/Observatoire Midi-Pyrénées) for their help in accessing the data. We also thank the PI investigators of the different AERONET stations and their staff for establishing and maintaining all the sites used in the present work. The MACC data come from the ECMWF website; MACC was funded between 2009 and 2011 as part of the 7th Framework Programme, pilot core GMES Atmospheric Service, under contract number 218793. Measurements at Lampedusa were supported by the Italian Ministry for University and Research through projects NextData and Ritmare. Lidar measurements in Barcelona were supported by the 7th Framework Programme project Aerosols, Clouds, and Trace Gases Research Infrastructure Network (ACTRIS) (grant agreement no. 262254) and by the Spanish Ministry of Science and Innovation and FEDER funds under the projects TEC2012-34575, TEC2009-09106/TEC, CGL2011-13580-E/CLI and CGL2011-16124-E/CLI. We also thank Dominique Carrer, Xavier Ceamanos and the ICARE centre for the AERUS-GEO data set. The data of the two Mediterranean buoys were obtained from the HyMeX program, sponsored by grants from MISTRALS/HyMeX and Météo-France. We also thank the Direction de la météorologie nationale in Morocco for providing us with the data in Fès. We thank Anaïs Culot and Emilie Bruhier for their help with the analysis of observation data and on the composite study.

Edited by: O. Dubovik

\section{References}

Artale, V., Calmanti, S., Carillo, A., Dell'Aquila, A., Herrmann, M., Pisacane, G., Ruti, P. M., Sannino, G., Struglia, M. V., Giorgi, F., Bi, X., Pal, J. S., Rauscher, S., and the PROTHEUS Group: An atmosphere-ocean regional climate model for the Mediterranean area: assessment of a present climate simulation, Clim. Dynam., 35, 721-740, doi:10.1007/s00382-009-0691-8, 2010.
Barnaba, F. and Gobbi, G. P.: Aerosol seasonal variability over the Mediterranean region and relative impact of maritime, continental and Saharan dust particles over the basin from MODIS data in the year 2001, Atmos. Chem. Phys., 4, 2367-2391, doi:10.5194/acp-4-2367-2004, 2004.

Benedetti, A., Kaiser, J. W., and Morcrette, J.-J.: [global climate] aerosols [in "state of the climate in 2010"], B. Am. Meteorol. Soc., 92, S65-S67, 2011.

Benkovitz, C. M., Scholz, M. T., Pacyna, J., Tarrason, L., Dignon, J., Voldner, E. C., Spiro, P. A., Logan, J. A., and Graedel, T. E.: Global gridded inventories of anthropogenic emissions of sulfur and nitrogen, J. Geophys. Res., 101, 29239-29253, 1996.

Bergamo, A., Tafuro, A. M., Kinne, S., De Tomasi, F., and Perrone, M. R.: Monthly-averaged anthropogenic aerosol direct radiative forcing over the Mediterranean based on AERONET aerosol properties, Atmos. Chem. Phys., 8, 6995-7014, doi:10.5194/acp8-6995-2008, 2008.

Beuvier, J., Sevault, F., Herrmann, M., Kontoyiannis, H., Ludwig, W., Rixen, M., Stanev, E., Béranger, K., and Somot, S.: Modeling the Mediterranean Sea interannual variability during 1961-2000: Focus on the Eastern Mediterranean Transient, J. Geophys. Res., 115, C08017, doi:10.1029/2009JC005950, 2010.

Carrer, D., Roujean, J.-L., Hautecoeur, O., and Elias, T.: Daily estimates of aerosol optical thickness over land surface based on a directional and temporal analysis of SEVIRI MSG visible observations, J. Geophys. Res., 115, D10208, doi:10.1029/2009JD012272, 2010.

Carrer, D., Ceamanos, X., Six, B., and Roujean, J.-L.: AERUSGEO: A newly available satellite- deriv ed aerosol optical depth product over Europe and Africa, Geophys. Res. Lett. , 41, 77317738, doi:10.1002/2014GL061707, 2014.

Colin, J., Déqué, M., Radu, R., and Somot, S.: Sensitivity study of heavy precipitation in Limited Area Model climate simulations: influence of the size of the domain and the use of the spectral nudging technique, Tellus, 62A, 591-604, 2010.

Dee, D. P., Uppala, S. M., Simmons, A. J., Berrisford, P., Poli, P., Kobayashi, S., Andrae, U., Balmaseda, M. A., Balsamo, G., Bauer, P., Bechtold, P., Beljaars, A. C. M., van de Berg, L., Bidlot, J., Bormann, N., Delsol, C., Dragani, R., Fuentes, M., Geer, A. J., Haimbergere, L., Healy, S. B., Hersbach, H., Hólm, E. V., Isaksen, L., Kallberg, P., Köhler, M., Matricardi, M., McNally, A. P., Monge-Sanzf, B. M., Morcrette, J.-J., Park, B.-K., Peubey, C., de Rosnaya, P., Tavolato, C., Thépaut, J.-N., and Vitart, F.: The ERA-Interim reanalysis: configuration and performance of the data assimilation system, Q. J. Roy. Meteor. Soc., 137, 553597, doi:10.1002/qj.828, 2011.

Déqué, M. and Somot, S.: Extreme precipitation and high resolution with Aladin, Idöjaras Quaterly Journal of the Hungarian Meteorological Service, 112, 179-190, 2008

Di Biagio, C., di Sarra, A., and Meloni, D.: Large atmospheric shortwave radiative forcing by Mediterranean aerosols derived from simultaneous ground-based and spaceborne observations and dependence on the aerosol type and single scattering albedo, J. Geophys. Res., 115, D10209, doi:10.1029/2009JD012697, 2010.

di Sarra, A., Pace, G., Meloni, D., De Silvestri, L., Piacentino, S., and Monteleone, F.: Surface shortwave radiative forcing of different aerosol types in the central Mediterranean, Geophys. Res. Lett., 35, L02714, doi:10.1029/2007GL032395, 2008. 
Gao, X., Pal, J. S., and Giorgi, F.: Projected changes in mean and extreme precipitation over the Mediterranean region from a high resolution double nested RCM simulation, Geophys. Res. Lett., 33, L03706, doi:10.1029/2005GL024954, 2006.

Gibelin, A.-L. and Déqué, M.: Anthropogenic climate change over the Mediterranean region simulated by a global variable resolution model, Clim. Dynam., 20, 327-339, doi:10.1007/s00382002-0277-1, 2003.

Ginoux, P., Chin, M., Tegen, I., Prospero, J., Holben, B. N., Dubovik, O., and Lin, S.-J.: Sources and distributions of dust aerosols simulated with the GOCART model, J. Geophys. Res., 106, 20255-20274, 2001.

Giorgi, F. and Lionello, P.: Climate change projections for the Mediterranean region, Global and Planetary Change, 63, 90-104, doi:10.1016/j.gloplacha.2007.09.005, 2008.

Giorgi, F., Coppola, E., Solmon, F., Mariotti, L., Sylla, M. B., Bi, X., Elguindi, N., Diro, G. T., Nair, V., Giuliani, G., Cozzini, S., Guettler, I., O’Brien, T. A., Tawfik, A. B., Shalaby, A., Zakey, A. S., Steiner, A. L., Stordal, F., Sloan, L. C., and Brankovic, C.: RegCM4: model description and preliminary tests over multiple CORDEX domains., Clim. Res., 52, 7-29, doi:10.3354/cr01018, 2012.

Gkikas, A., Houssos, E., Hatzianastassiou, N., Papadimas, C., and Bartzokas, A.: Synoptic conditions favouring the occurrence of aerosol episodes over the broader Mediterranean basin, Q. J. Roy. Meteor. Soc., 138, 932-949, doi:10.1002/qj.978, 2012.

Gkikas, A., Hatzianastassiou, N., Mihalopoulos, N., Katsoulis, V., Kazadzis, S., Pey, J., Querol, X., and Torres, O.: The regime of intense desert dust episodes in the Mediterranean based on contemporary satellite observations and ground measurements, Atmos. Chem. Phys., 13, 12135-12154, doi:10.5194/acp-1312135-2013, 2013.

Guelle, W., Schulz, M., Balkanski, Y., and Dentener, F.: Influence of the source formulation on modeling the atmospheric global distribution of the sea salt aerosol, J. Geophys. Res., 106, 2750927524, 2001.

Guieu, C., Dulac, F., Desboeufs, K., Wagener, T., Pulido-Villena, E., Grisoni, J.-M., Louis, F., Ridame, C., Blain, S., Brunet, C., Bon Nguyen, E., Tran, S., Labiadh, M., and Dominici, J.-M.: Large clean mesocosms and simulated dust deposition: a new methodology to investigate responses of marine oligotrophic ecosystems to atmospheric inputs, Biogeosciences, 7, 27652784, doi:10.5194/bg-7-2765-2010, 2010.

Herrmann, M., Somot, S., Calmanti, S., Dubois, C., and Sevault, F.: Representation of spatial and temporal variability of daily wind speed and of intense wind events over the Mediterranean Sea using dynamical downscaling: impact of the regional climate model configuration, Nat. Hazards Earth Syst. Sci., 11, 19832001, doi:10.5194/nhess-11-1983-2011, 2011.

Holben, B. N., Eck, T. F., Slutsker, I., Tanré, D., Buis, J. P., Setzer, A., Vermote, E., Reagan, J. A., Kaufman, Y., Nakajima, T., Lavenu, F., Jankowiak, I., and Smirnov, A.: AERONET-A Federated Instrument Network and Data Archive for Aerosol Characterization, Remote Sens. Environ., 66, 1-16, doi:10.1016/S00344257(98)00031-5, 1998.

Holben, B. N., Tanré, D., Smirnov, A., Eck, T. F., Slutsker, I., Abuhassan, N., Newcomb, W. W., Schafer, J. S., Chatenet, B., Lavenu, F., Kaufman, Y. J., Castle, J. V., Setzer, A., Markham, B., Clark, D., Frouin, R., Halthore, R., Karneli, A., O'Neill,
N. T., Pietras, C., Pinker, R. T., Voss, K., and Zibordi, G.: An emerging ground-based aerosol climatology: Aerosol optical depth from AERONET, J. Geophys. Res., 106, 12067-12097, doi:10.1029/2001JD900014, 2001.

Huneeus, N., Schulz, M., Balkanski, Y., Griesfeller, J., Prospero, J., Kinne, S., Bauer, S., Boucher, O., Chin, M., Dentener, F., Diehl, T., Easter, R., Fillmore, D., Ghan, S., Ginoux, P., Grini, A., Horowitz, L., Koch, D., Krol, M. C., Landing, W., Liu, X., Mahowald, N., Miller, R., Morcrette, J.-J., Myhre, G., Penner, J., Perlwitz, J., Stier, P., Takemura, T., and Zender, C. S.: Global dust model intercomparison in AeroCom phase I, Atmos. Chem. Phys., 11, 7781-7816, doi:10.5194/acp-11-7781-2011, 2011.

Israelevich, P., Ganor, E., Alpert, P., Kishcha, P., and Stupp, A.: Predominant transport paths of Saharan dust over the Mediterranean Sea to Europe, J. Geophys. Res., 117, D02205, doi:10.1029/2011JD016482, 2012.

Jaeglé, L., Quinn, P. K., Bates, T. S., Alexander, B., and Lin, J.-T.: Global distribution of sea salt aerosols: new constraints from in situ and remote sensing observations, Atmos. Chem. Phys., 11, 3137-3157, doi:10.5194/acp-11-3137-2011, 2011.

Kahn, R. A., Gaitley, B. J., Martonchik, J. V., Diner, D. J., Crean, K. A., and Holben, B.: Multiangle imaging spectroradiometer (misr) global aerosol optical depth validation based on 2 years of coincident aerosol robotic network (aeronet) observations, J. Geophys. Res., 110, D10S04, doi:10.1029/2004JD004706, 2005.

Kahn, R. A., Gaitley, B. J., Garay, M. J., Diner, D. J., Eck, T. F., Smirnov, A., and Holben, B. N.: Multiangle Imaging SpectroRadiometer global aerosol product assessment by comparison with the Aerosol Robotic Network, J. Geophys. Res., 115, D23209, doi:10.1029/2010JD014601, 2010.

Knippertz, P. and Todd, M. C.: Mineral dust aerosols over the Sahara: meteorological controls on emission and transport and implications for modeling, Rev. Geophys., 50, RG1007, doi:10.1029/2011RG000362, 2012.

Kok, J. F.: A scaling theory for the size distribution of emitted dust aerosols suggests climate models underestimate the size of the global dust cycle, P. Natl. Acad. Sci. USA, 108, 1016-1021, doi:10.1073/pnas.1014798108, 2011.

Krzic, A., Tosic, I., Djurdjevic, V., Veljovic, K., and Rajkovic, B.: Changes in climate indices for Serbia according to the SRES-A1B and SRES-A2 scenarios, Clim. Res., 49, 73-86, doi:10.3354/cr01008, 2011.

Lamarque, J.-F., Bond, T. C., Eyring, V., Granier, C., Heil, A., Klimont, Z., Lee, D., Liousse, C., Mieville, A., Owen, B., Schultz, M. G., Shindell, D., Smith, S. J., Stehfest, E., Van Aardenne, J., Cooper, O. R., Kainuma, M., Mahowald, N., McConnell, J. R., Naik, V., Riahi, K., and van Vuuren, D. P.: Historical (1850-2000) gridded anthropogenic and biomass burning emissions of reactive gases and aerosols: methodology and application, Atmos. Chem. Phys., 10, 7017-7039, doi:10.5194/acp10-7017-2010, 2010.

Lamarque, J.-F., Shindell, D. T., Josse, B., Young, P. J., Cionni, I., Eyring, V., Bergmann, D., Cameron-Smith, P., Collins, W. J., Doherty, R., Dalsoren, S., Faluvegi, G., Folberth, G., Ghan, S. J., Horowitz, L. W., Lee, Y. H., MacKenzie, I. A., Nagashima, T., Naik, V., Plummer, D., Righi, M., Rumbold, S. T., Schulz, M., Skeie, R. B., Stevenson, D. S., Strode, S., Sudo, K., Szopa, S., Voulgarakis, A., and Zeng, G.: The Atmospheric Chemistry and Climate Model Intercomparison Project (ACCMIP): overview 
and description of models, simulations and climate diagnostics, Geosci. Model Dev., 6, 179-206, doi:10.5194/gmd-6-179-2013, 2013.

Lelieveld, J., Berresheim, H., Borrmann, S., Crutzen, P. J., Dentener, F. J., Fischer, H., Feichter, J., Flatau, P. J., Heland, J., Holzinger, R., Korrmann, R., Lawrence, M. G., Levin, Z., Markowicz, K. M., Mihalopoulos, N., Minikin, A., Ramanathan, V., de Reus, M., Roelofs, G. J., Scheeren, H. A., Sciare, J., Schlager, H., Schultz, M., Siegmund, P., Steil, B., Stephanou, E. G., Stier, P., Traub, M., Warneke, C., Williams, J., and Ziereis, H.: Global Air Pollution Crossroads over the Mediterranean, Science, 298, 794-799, doi:10.1126/science.1075457, 2002.

Levy, R. C., Remer, L. A., Mattoo, S., Vermote, E. F., and Kaufman, Y. J.: Second-generation operational algorithm: Retrieval of aerosol properties over land from inversion of Moderate Resolution Imaging Spectroradiometer spectral reflectance, J. Geophys. Res., 112, D13211, doi:10.1029/2006JD007811, 2007.

Levy, R. C., Remer, L. A., Kleidman, R. G., Mattoo, S., Ichoku, C., Kahn, R., and Eck, T. F.: Global evaluation of the Collection 5 MODIS dark-target aerosol products over land, Atmos. Chem. Phys., 10, 10399-10420, doi:10.5194/acp-10-10399-2010, 2010.

Lucas-Picher, P., Somot, S., Déqué, M., Decharme, B., and Alias, A.: Evaluation of the regional climate model ALADIN to simulate the climate over North America in the CORDEX framework, Clim. Dynam., 41, 1117-1137, doi:10.1007/s00382-012-1613-8, 2013.

Léon, J.-F., Augustin, P., Mallet, M., Pont, V., Dulac, F., Fourmentin, M., and Lambert, D.: Aerosol vertical distribution, optical properties and transport over Corsica (Western Mediterranean), Atmos. Chem. Phys. Discuss., submitted, 2015.

L'Hévéder, B., Li, L., Sevault, F., and Somot, S.: Interannual variability of deep convection in the Northwestern Mediterranean simulated with a coupled AORCM, Clim. Dynam., Clim. Dynam., 41, 937-960, doi:10.1007/s00382-012-1527-5, 2012.

Mahowald, N., Albani, S., Kok, J. F., Engelstaeder, S., Scanza, R., Ward, D. S., and Flanner, M. G.: The size distribution of desert dust aerosols and its impact on the Earth system, Aeolian Research, 15, 53-71, doi:10.1016/j.aeolia.2013.09.002, 2013.

Mariotti, A. and Dell'Aquila, A.: Decadal climate variability in the Mediterranean region: roles of large-scale forcings and regional processes, Clim. Dynam., 38, 1129-1145, doi:10.1007/s00382011-1056-7, 2012.

Marticorena, B. and Bergametti, G.: Modeling the atmosphere dust cycle: 1. Design of a soil-derived dust emission scheme, J. Geophys. Res., 100, 16415-16430, 1995.

Masson, V., Champeaux, J., Chauvin, F., Meriguet, C., and Lacaze, R.: A global database of land surface parameters at 1-km resolution in meteorological and climate models, J. Climate, 16, 12611282,2003

Meier, J., Tegen, I., Heinold, B., and Wolke, R.: Direct and semidirect radiative effects of absorbing aerosols in Europe: Results from a regional model, Geophys. Res. Lett., 39, L09802, doi:10.1029/2012GL050994, 2012.

Michou, M., Nabat, P., and Saint-Martin, D.: Development and basic evaluation of a prognostic aerosol scheme (v1) in the CNRM Climate Model CNRM-CM6, Geosci. Model Dev., 8, 501-531, doi:10.5194/gmd-8-501-2015, 2015.
Middleton, N. J. and Goudie, A. S.: Saharan dust: sources and trajectories, T. I. Brit. Geogr., 26, 165-181, doi:10.1111/14755661.00013, 2001.

Mlawer, E. J., Taubman, S. J., Brown, P. D., Iacono, M. J., and Clough, S. A.: Radiative transfer for inhomogeneous atmospheres: RRTM, a validated correlated-k model for the longwave, J. Geophys. Res., 102, 16663-16682, 1997.

Morcrette, J.-J.: Description of the Radiation Scheme in the ECMWF Model, Tech. rep., ECMWF, Reading, UK, 165 pp., 1989.

Morcrette, J.-J., Boucher, O., Jones, L., Salmond, D., Bechtold, P., Beljaars, A., Benedetti, A., Bonet, A., Kaiser, J. W., Razinger, M., Schulz, M., Serrar, S., Simmons, J., Sofiev, M., Suttie, M., Tompkins, A. M., and Untch, A.: Aerosol analysis and forecast in the european centre for medium-range weather forecasts integrated forecast system: Forward modeling, J. Geophys. Res., 114, D06206, doi:10.1029/2008JD011235, 2009.

Moulin, C., Guillard, F., Dulac, F., and Lambert, C. E.: Longterm daily monitoring of Saharan dust load over ocean using Meteosat ISCCP-B2 data 1. Methodology and preliminary results for 1983-1994 in the Mediterranean, J. Geophys. Res., 102, 16947-16958, 1997.

Moulin, C., Lambert, C. E., Dayan, U., Masson, V., Ramonet, M., Bousquet, P., Legrand, M., Balkanski, Y. J., Guelle, W., Marticorena, B., Bergametti, G., and Dulac, F.: Satellite climatology of African dust transport in the Mediterranean atmosphere, J. Geophys. Res., 103, 13137-13144, doi:10.1029/98JD00171, 1998.

Nabat, P., Solmon, F., Mallet, M., Kok, J. F., and Somot, S.: Dust emission size distribution impact on aerosol budget and radiative forcing over the Mediterranean region: a regional climate model approach, Atmos. Chem. Phys., 12, 10545-10567, doi:10.5194/acp-12-10545-2012, 2012.

Nabat, P., Somot, S., Mallet, M., Chiapello, I., Morcrette, J. J., Solmon, F., Szopa, S., Dulac, F., Collins, W., Ghan, S., Horowitz, L. W., Lamarque, J. F., Lee, Y. H., Naik, V., Nagashima, T., Shindell, D., and Skeie, R.: A 4-D climatology (1979-2009) of the monthly tropospheric aerosol optical depth distribution over the Mediterranean region from a comparative evaluation and blending of remote sensing and model products, Atmos. Meas. Tech., 6, 1287-1314, doi:10.5194/amt-6-1287-2013, 2013.

Nabat, P., Somot, S., Mallet, M., Sevault, F., Chiacchio, M., and Wild, M.: Direct and semi-direct aerosol radiative effect on the Mediterranean climate variability using a Regional Climate System Model, Clim. Dynam., 44, 1127-1155, doi:10.1007/s00382014-2205-6, 2015.

Noilhan, J. and Mahfouf, J.-F.: The ISBA land surface parameterisation scheme, Global Planet. Change, 13, 145-159, doi:10.1016/0921-8181(95)00043-7, 1996.

Papadimas, C. D., Hatzianastassiou, N., Mihalopoulos, N., Querol, $\mathrm{X}$., and Vardavas, I.: Spatial and temporal variability in aerosol properties over the Mediterranean basin based on 6year (2000-2006) MODIS data, J. Geophys. Res., 113, D11205, doi:10.1029/2007JD009189, 2008.

Pappalardo, G., Amodeo, A., Apituley, A., Comeron, A., Freudenthaler, V., Linné, H., Ansmann, A., Bösenberg, J., D’Amico, G., Mattis, I., Mona, L., Wandinger, U., Amiridis, V., AladosArboledas, L., Nicolae, D., and Wiegner, M.: EARLINET: towards an advanced sustainable European aerosol lidar network, 
Atmos. Meas. Tech. Discuss., 7, 2929-2980, doi:10.5194/amtd7-2929-2014, 2014.

Quaas, J., Ming, Y., Menon, S., Takemura, T., Wang, M., Penner, J. E., Gettelman, A., Lohmann, U., Bellouin, N., Boucher, O., Sayer, A. M., Thomas, G. E., McComiskey, A., Feingold, G., Hoose, C., Kristjánsson, J. E., Liu, X., Balkanski, Y., Donner, L. J., Ginoux, P. A., Stier, P., Grandey, B., Feichter, J., Sednev, I., Bauer, S. E., Koch, D., Grainger, R. G., Kirkevåg, A., Iversen, T., Seland, Ø., Easter, R., Ghan, S. J., Rasch, P. J., Morrison, H., Lamarque, J.-F., Iacono, M. J., Kinne, S., and Schulz, M.: Aerosol indirect effects - general circulation model intercomparison and evaluation with satellite data, Atmos. Chem. Phys., 9, 8697-8717, doi:10.5194/acp-9-8697-2009, 2009.

Radu, R., Déqué, M., and Somot, S.: Spectral nudging in a spectral regional climate model, Tellus, 60A, 898-910, doi:10.1111/j.1600-0870.2008.00341.x, 2008.

Reba, M. N. M., Rocadenbosch, F., Sicard, M., Kumar, D., and Tomás, S.: On the lidar ratio estimation from the synergy between AERONET sun-photometer data and elastic lidar inversion, Proc. of the 25th International Laser Radar Conference, Saint-Petersburg (Rusia), 5-9 July 2010, 1102-1105, ISBN 9785-94458-109-9, 2010.

Santese, M., Perrone, M. R., Zakey, A. S., De Tomasi, F., and Giorgi, F.: Modeling of Saharan dust outbreaks over the Mediterranean by RegCM3: case studies, Atmos. Chem. Phys., 10, 133156, doi:10.5194/acp-10-133-2010, 2010.

Schulz, M., de Leeuw, G., and Balkanski, Y.: Sea-salt aerosol source functions and emissions, in: Emission of Atmospheric Trace Compounds, edited by: Granier, C., Artaxo, P., and Reeves, C. E., Kluwer Acad., Norwell, Mass., Springer Netherlands, 333359, 2004.

Schulz, M., Textor, C., Kinne, S., Balkanski, Y., Bauer, S., Berntsen, T., Berglen, T., Boucher, O., Dentener, F., Guibert, S., Isaksen, I. S. A., Iversen, T., Koch, D., Kirkevåg, A., Liu, X., Montanaro, V., Myhre, G., Penner, J. E., Pitari, G., Reddy, S., Seland, $\varnothing$., Stier, P., and Takemura, T.: Radiative forcing by aerosols as derived from the AeroCom present-day and pre-industrial simulations, Atmos. Chem. Phys., 6, 5225-5246, doi:10.5194/acp-65225-2006, 2006.

Somot, S., Sevault, F., Déqué, M., and Crépon, M.: 21st century climate change scenario for the Mediterranean using a coupled atmosphere-ocean regional climate model, Global Planet. Change, 63, 112-126, doi:10.1016/j.gloplacha.2007.10.003, 2008.

Spyrou, C., Kallos, G., Mitsakou, C., Athanasiadis, P., Kalogeri, C., and Iacono, M. J.: Modeling the radiative effects of desert dust on weather and regional climate, Atmos. Chem. Phys., 13, 54895504, doi:10.5194/acp-13-5489-2013, 2013.

Tanré, D., Geleyn, J., and Slingo, J.: First results of the introduction of an advanced aerosol radiation interaction in ECMWF low resolution global model, in Aerosols and Their Climatic Effects, edited by: Gerber, H. and Deepak, A., pp. 133-177, A. Deepak, Hampton, Va, 1984.

Tanré, D., Kaufman, Y. J., Herman, M., and Mattoo, S.: Remote sensing of aerosol properties over oceans using the MODIS/EOS spectral radiances, J. Geophys. Res., 102, 16971-16988, 1997.
Taylor, K. E.: Summarizing multiple aspects of model performance in a single diagram, J. Geophys. Res., 106, 7183-7192, doi:10.1029/2000JD900719, 2001.

Tegen, I., Hollrig, P., Chin, M., Fung, I., Jacob, D., and Penner, J.: Contribution of different aerosol species to the global aerosol extinction optical thickness: Estimates from model results, J. Geophys. Res., 102, 23895-23915, 1997.

Tesche, M., Ansmann, A., Müller, D., Althausen, D., Mattis, I., Heese, B., Freundenthaler, V., Wiegner, M., Esselborn, M., Pisani, G., and Knippertz, P.: Vertical profiling of Saharan dust with Raman lidars and airborne HSRL in southern Morocco during SAMUM, Tellus B, 61, 144-164, doi:10.1111/j.16000889.2008.00390.x, 2009.

Textor, C., Schulz, M., Guibert, S., Kinne, S., Balkanski, Y., Bauer, S., Berntsen, T., Berglen, T., Boucher, O., Chin, M., Dentener, F., Diehl, T., Easter, R., Feichter, H., Fillmore, D., Ghan, S., Ginoux, P., Gong, S., Grini, A., Hendricks, J., Horowitz, L., Huang, P., Isaksen, I., Iversen, I., Kloster, S., Koch, D., Kirkevåg, A., Kristjansson, J. E., Krol, M., Lauer, A., Lamarque, J. F., Liu, X., Montanaro, V., Myhre, G., Penner, J., Pitari, G., Reddy, S., Seland, $\varnothing .$, Stier, P., Takemura, T., and Tie, X.: Analysis and quantification of the diversities of aerosol life cycles within AeroCom, Atmos. Chem. Phys., 6, 1777-1813, doi:10.5194/acp-6-1777-2006, 2006.

Todd, M. C., Karam, D. B., Cavazos, C., Bouet, C., Heinold, B., Baldasano, J. M., Cautenet, G., Koren, I., Perez, C., Solmon, F., Tegen, I., Tulet, P., Washington, R., and Zakey, A.: Quantifying uncertainty in estimates of mineral dust flux: An intercomparison of model performance over the Bodélé Depression, northern Chad, J. Geophys. Res., 113, D24107, doi:10.1029/2008JD010476, 2008.

Turuncoglu, U. U., Giuliani, G., Elguindi, N., and Giorgi, F.: Modelling the Caspian Sea and its catchment area using a coupled regional atmosphere-ocean model (RegCM4-ROMS): model design and preliminary results, Geosci. Model Dev., 6, 283-299, doi:10.5194/gmd-6-283-2013, 2013.

Valcke, S.: The OASIS3 coupler: a European climate modelling community software, Geosci. Model Dev., 6, 373-388, doi:10.5194/gmd-6-373-2013, 2013.

Vogel, B., Vogel, H., Bäumer, D., Bangert, M., Lundgren, K., Rinke, R., and Stanelle, T.: The comprehensive model system COSMOART - Radiative impact of aerosol on the state of the atmosphere on the regional scale, Atmos. Chem. Phys., 9, 8661-8680, doi:10.5194/acp-9-8661-2009, 2009.

Woodage, M. J., Slingo, A., Woodward, S., and Comer, R. E.: Simulations of Desert Dust and Biomass Burning Aerosols with a High-Resolution Atmospheric GCM, J. Climate, 23, 1636-1659, doi:10.1175/2009JCLI2994.1, 2010.

Zanis, P.: A study on the direct effect of anthropogenic aerosols on near surface air temperature over Southeastern Europe during summer 2000 based on regional climate modeling, Ann. Geophys., 27, 3977-3988, doi:10.5194/angeo-27-3977-2009, 2009.

Zanis, P., Ntogras, C., Zakey, A., Pytharoulis, I., and Karacostas, T.: Regional climate feedback of anthropogenic aerosols over Europe using RegCM3, Clim. Res., 52, 267-278, doi:10.3354/cr01070, 2012. 